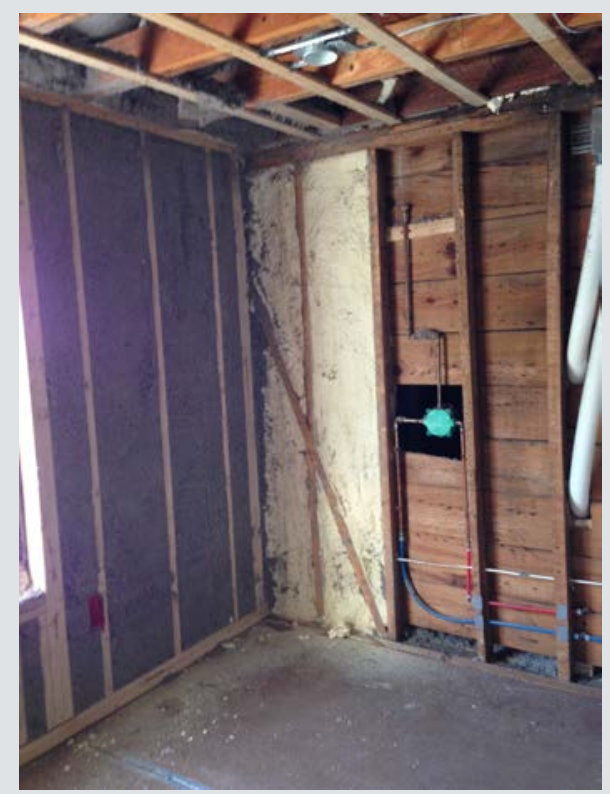

\title{
Measure Guideline: Deep Energy Enclosure Retrofit for Double-Stud Walls
}

H. Loomis and B. Pettit Building Science Corporation

June 2015

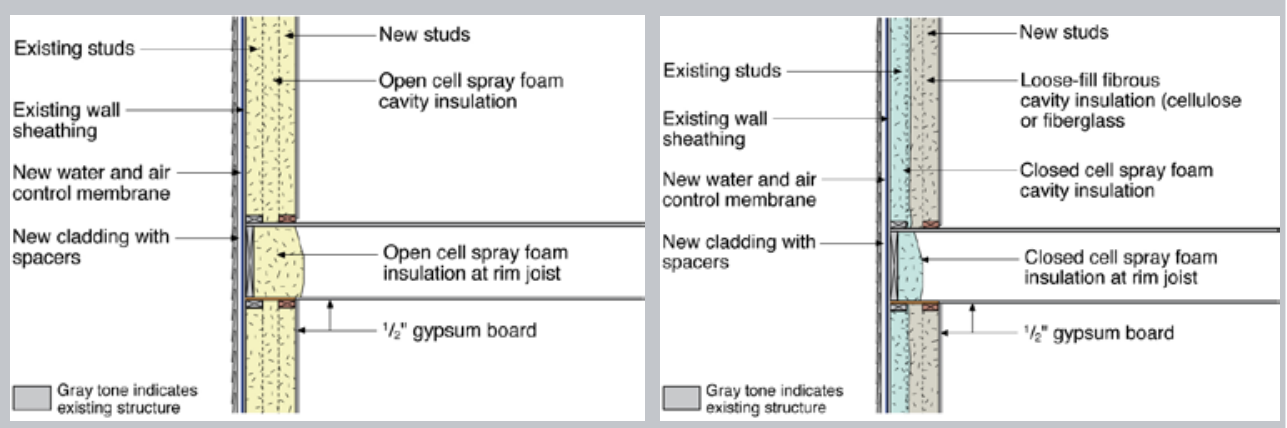




\section{NOTICE}

This report was prepared as an account of work sponsored by an agency of the United States government. Neither the United States government nor any agency thereof, nor any of their employees, subcontractors, or affiliated partners makes any warranty, express or implied, or assumes any legal liability or responsibility for the accuracy, completeness, or usefulness of any information, apparatus, product, or process disclosed, or represents that its use would not infringe privately owned rights. Reference herein to any specific commercial product, process, or service by trade name, trademark, manufacturer, or otherwise does not necessarily constitute or imply its endorsement, recommendation, or favoring by the United States government or any agency thereof. The views and opinions of authors expressed herein do not necessarily state or reflect those of the United States government or any agency thereof.

Available electronically at http://www.osti.gov/scitech

Available for a processing fee to U.S. Department of Energy and its contractors, in paper, from:

U.S. Department of Energy

Office of Scientific and Technical Information

P.O. Box 62

Oak Ridge, TN 37831-0062

phone: 865.576 .8401

fax: 865.576 .5728

email: mailto:reports@adonis.osti.gov

Available for sale to the public, in paper, from:

U.S. Department of Commerce

National Technical Information Service

5285 Port Royal Road

Springfield, VA 22161

phone: 800.553 .6847

fax: 703.605.6900

email: orders@ntis.fedworld.gov

online ordering: http://www.ntis.gov/help/ordermethods.aspx 


\title{
Measure Guideline: Deep Energy Enclosure Retrofit for Double-Stud Walls
}

\author{
Prepared for: \\ The National Renewable Energy Laboratory \\ On behalf of the U.S. Department of Energy's Building America Program \\ Office of Energy Efficiency and Renewable Energy \\ 15013 Denver West Parkway \\ Golden, CO 80401 \\ NREL Contract No. DE-AC36-08GO28308
}

\author{
Prepared by: \\ H. Loomis and B. Pettit \\ Building Science Corporation \\ 3 Lan Drive, Suite 102 \\ Westford, MA 01886 \\ NREL Technical Monitor: Stacey Rothgeb \\ Prepared under Subcontract No. KNDJ-0-40337-05
}

June 2015 
The work presented in this report does not represent performance of any product relative to regulated minimum efficiency requirements.

The laboratory and/or field sites used for this work are not certified rating test facilities. The conditions and methods under which products were characterized for this work differ from standard rating conditions, as described.

Because the methods and conditions differ, the reported results are not comparable to rated product performance and should only be used to estimate performance under the measured conditions. 


\section{Table of Contents}

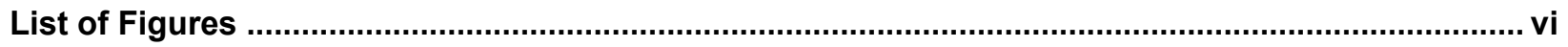

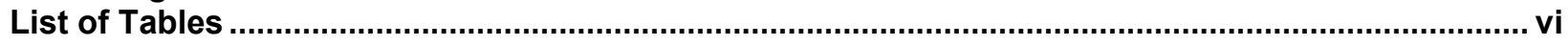

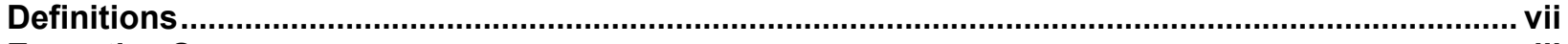

Executive Summary .............................................................................................................. viii

Progression Summary: Deep Energy Enclosure Retrofit for Double-Stud Wall With New Cladding 1

Progression Summary: Deep Energy Enclosure Retrofit for Double-Stud Wall With Existing

Cladding ...

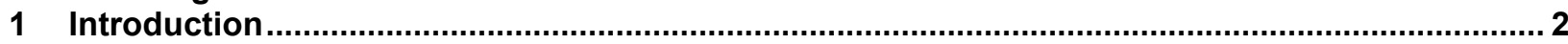

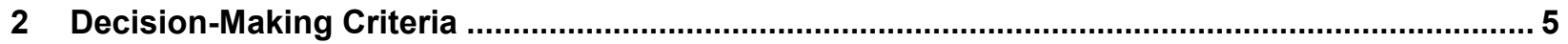

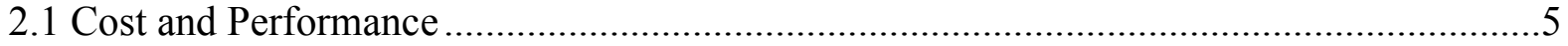

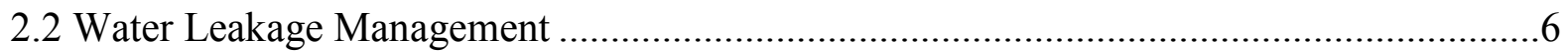

2.3 Air Leakage Management.......................................................................................

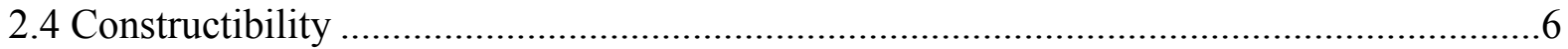

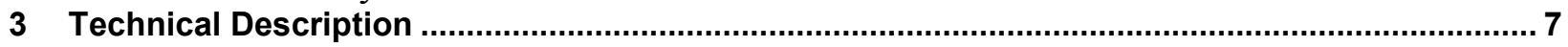

3.1 Double-Stud Wall Assembly: Replace Cladding ..................................................... 7

3.2 Double-Stud Wall Assembly: Retain Cladding .........................................................

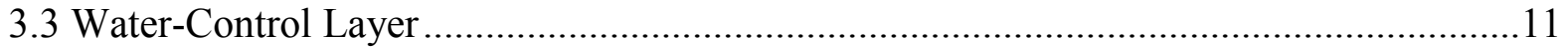

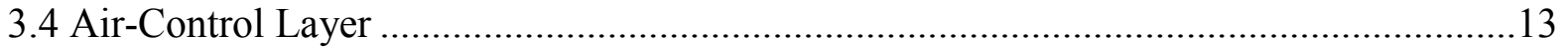

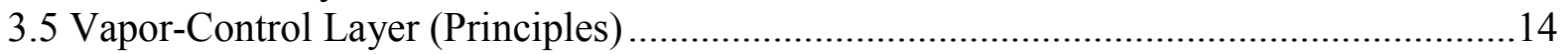

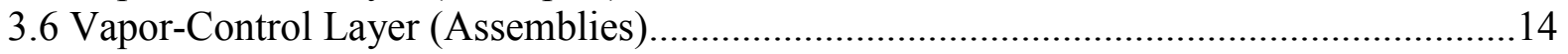

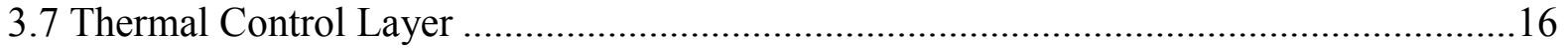

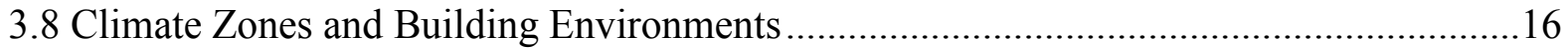

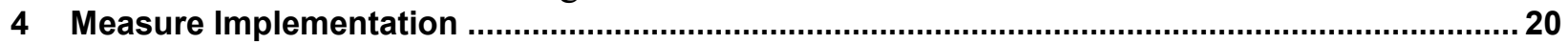

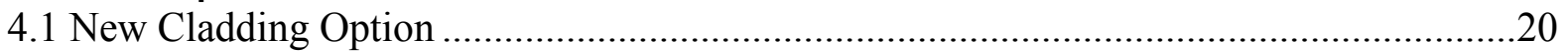

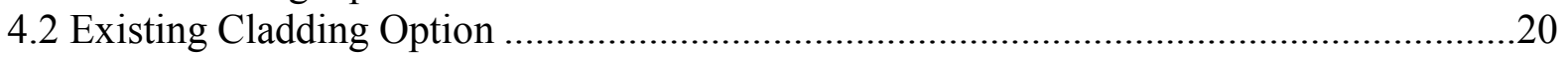

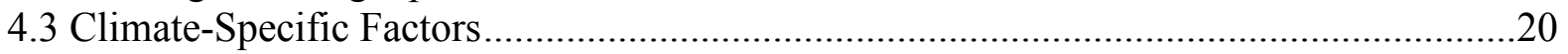

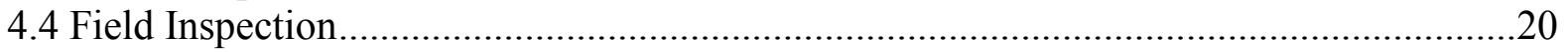

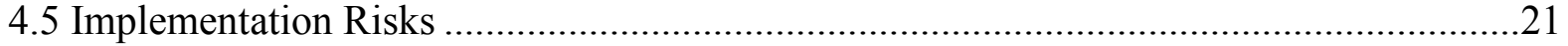

4.6 Installation Procedure for New Cladding Option ......................................................2 21

A. Remove existing wall cladding and trim; prepare wall sheathing for water- and

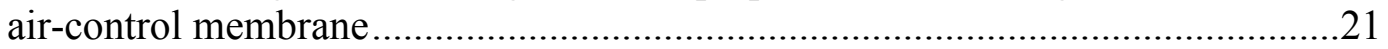

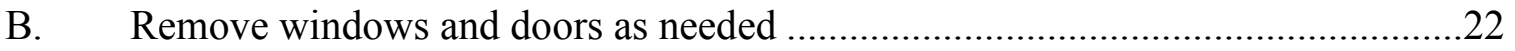

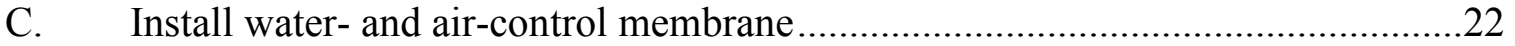

D. Install flashings, air-control transitions, windows, and doors ..............................23

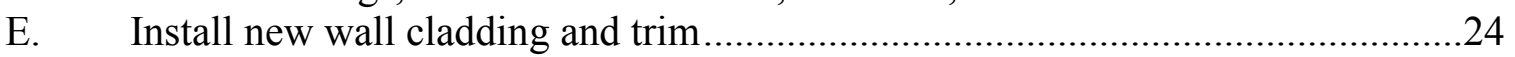

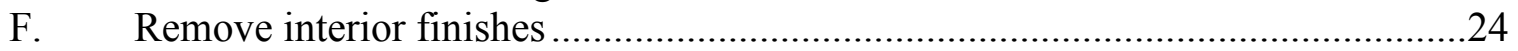

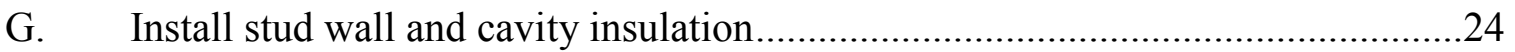

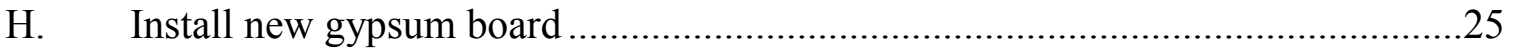

4.7 Installation Procedure for Existing Cladding Option..................................................26

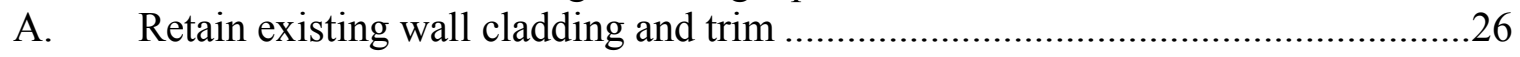

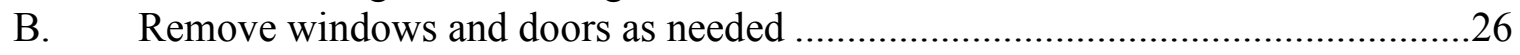

C. Install flashings, air-control transitions, windows, and doors .............................26

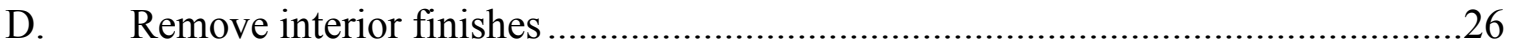

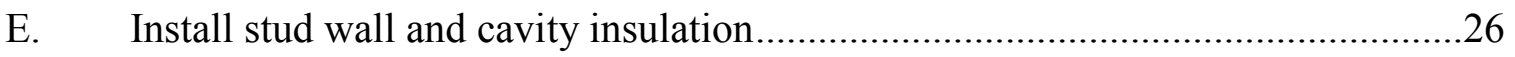

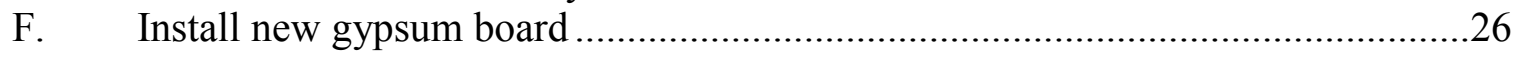

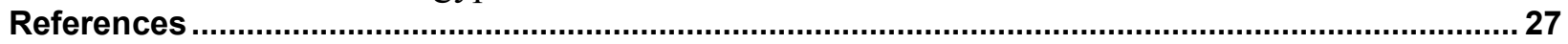




\section{List of Figures}

Figure 1. New cladding approach—double-stud wall with cellulose insulation................................ 7

Figure 2. New cladding approach-double-stud wall with ocSPF insulation ..................................... 8

Figure 3. New cladding approach-double-stud wall with ccSPF and fibrous insulation .................. 8

Figure 4. Existing cladding approach—double-stud wall with ocSPF insulation ........................... 10

Figure 5. Existing cladding approach-double-stud wall with ccSPF and fibrous insulation.......... 10

Figure 6. The "down" and "out" approach to flashing (left); flashing integrated with the watercontrol layer with lapped joints (right) ................................................................................... 11

Figure 7. Head and sill window detail at double-stud wall with new cladding .................................. 12

Figure 8. Head and sill window detail at double-stud wall with existing cladding............................. 12

Figure 9. U.S. Department of Energy climate zones................................................................... 17

Figure 10. Hygrothermal map, Lstiburek 2006 ...................................................................... 18

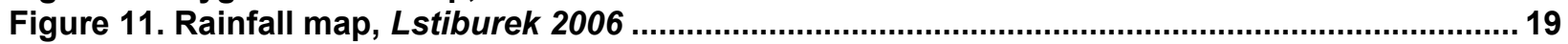

Figure 12. Exterior finishes are removed and existing wall sheathing is exposed. ......................... 22

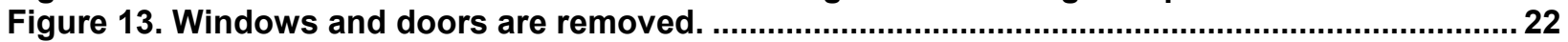

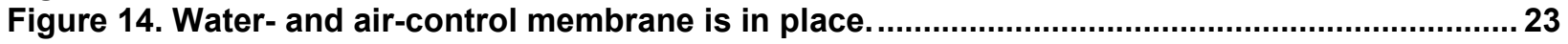

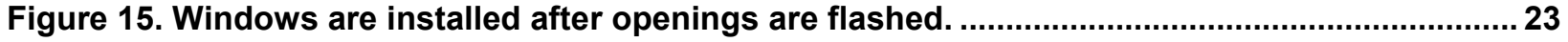

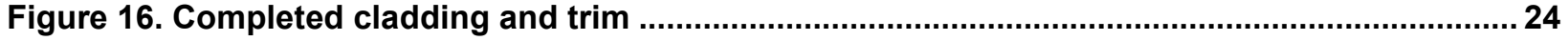

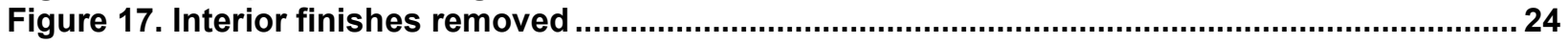

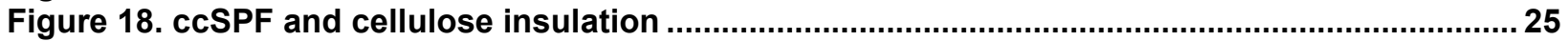

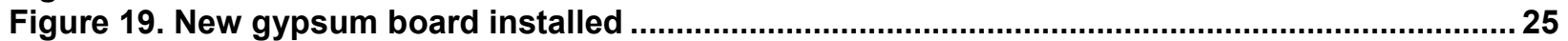

Unless otherwise noted, all figures were created by BSC.

\section{List of Tables}

Table 1. Unit Costs for Double-Stud Wall Retrofit Components $\left(\$ / \mathrm{ft}^{2}\right)$ per RS Means ${ }^{\star} \ldots . . . . . . . . . . . . . . . . .5$

Table 2. Vapor Retarder Classes (2009 IRC and 2012 IRC).............................................................. 14

Table 3. Thermal Resistance Values To Control Condensation Using Exterior Insulating Sheathing

for Climate Zones 5, 6, 7, 8, and Marine 4 From (2009 IRC and 2012 IRC) ............................... 15

Table 4. Recommended Minimum R-Value for Wall Enclosures....................................................... 16

Unless otherwise noted, all tables were created by BSC. 


\section{Definitions}

ccSPF Closed-Cell Spray Polyurethane Foam

IECC International Energy Conservation Code

IRC International Residential Code for One- and Two-Family Dwellings

ocSPF Open-Cell Spray Polyurethane Foam

RH Relative Humidity 


\section{Executive Summary}

This Measure Guideline describes a deep energy enclosure retrofit solution that provides insulation to the interior of the wall assembly with the use of a double-stud wall. The guide describes two approaches to retrofitting the existing walls - one that involves replacing the existing cladding and the other that leaves the cladding in place. This guideline also covers the design principles related to the use of various insulation types and provides strategies and procedures for implementing the double-stud wall retrofit. It also includes an evaluation of important moisture-related and indoor air quality measures that need to be implemented to achieve a durable high-performance wall.

The U.S. Department of Energy's research Team Building Science Corporation wrote this Measure Guideline to support contractors who are implementing an interior insulation highperformance enclosure retrofit and designers who want to design such retrofits. The guideline can also inform building owners about strategies that are available for deep energy enclosure retrofits of wood-framed residential buildings.

This Measure Guideline is important to the high-performance retrofit industry because it demonstrates techniques for implementing double-stud walls in high-performance enclosure retrofits. The information is based on the latest research performed for the U.S. Department of Energy Building America program. 


\section{Progression Summary: Deep Energy Enclosure Retrofit for Double-Stud Wall With New Cladding}
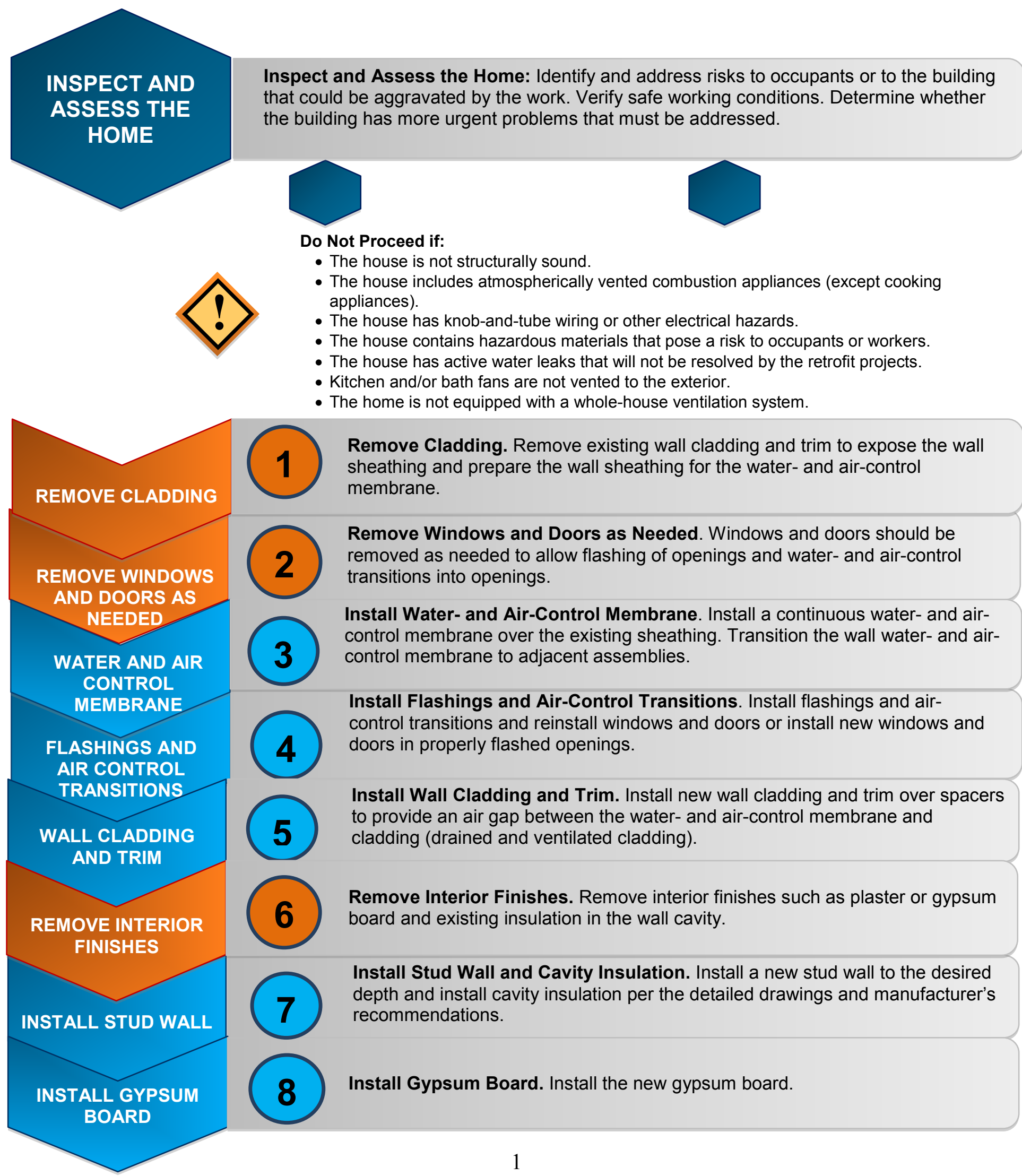


\section{Progression Summary: Deep Energy Enclosure Retrofit for Double-Stud Wall With Existing Cladding}

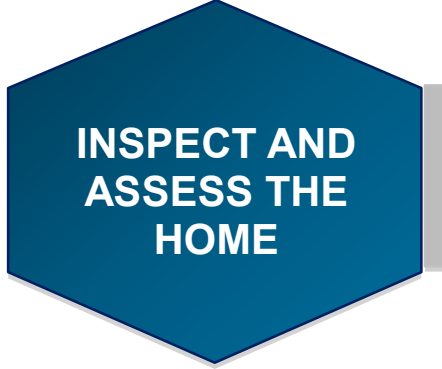

Inspect and Assess the Home: Identify and address risks to occupants or to the building that could be aggravated by the work. Verify safe working conditions. Determine whether the building has more urgent problems that must be addressed.

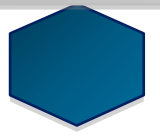

Do Not Proceed if:

- The house is not structurally sound.

- The house includes atmospherically vented combustion appliances (except cooking appliances).

- The house has knob-and-tube wiring or other electrical hazards.

- The house contains hazardous materials that pose a risk to occupants or workers.

- The house has active water leaks that will not be resolved by the retrofit projects.

- Kitchen and/or bath fans are not vented to the exterior.

- The home is not equipped with a whole-house ventilation system.

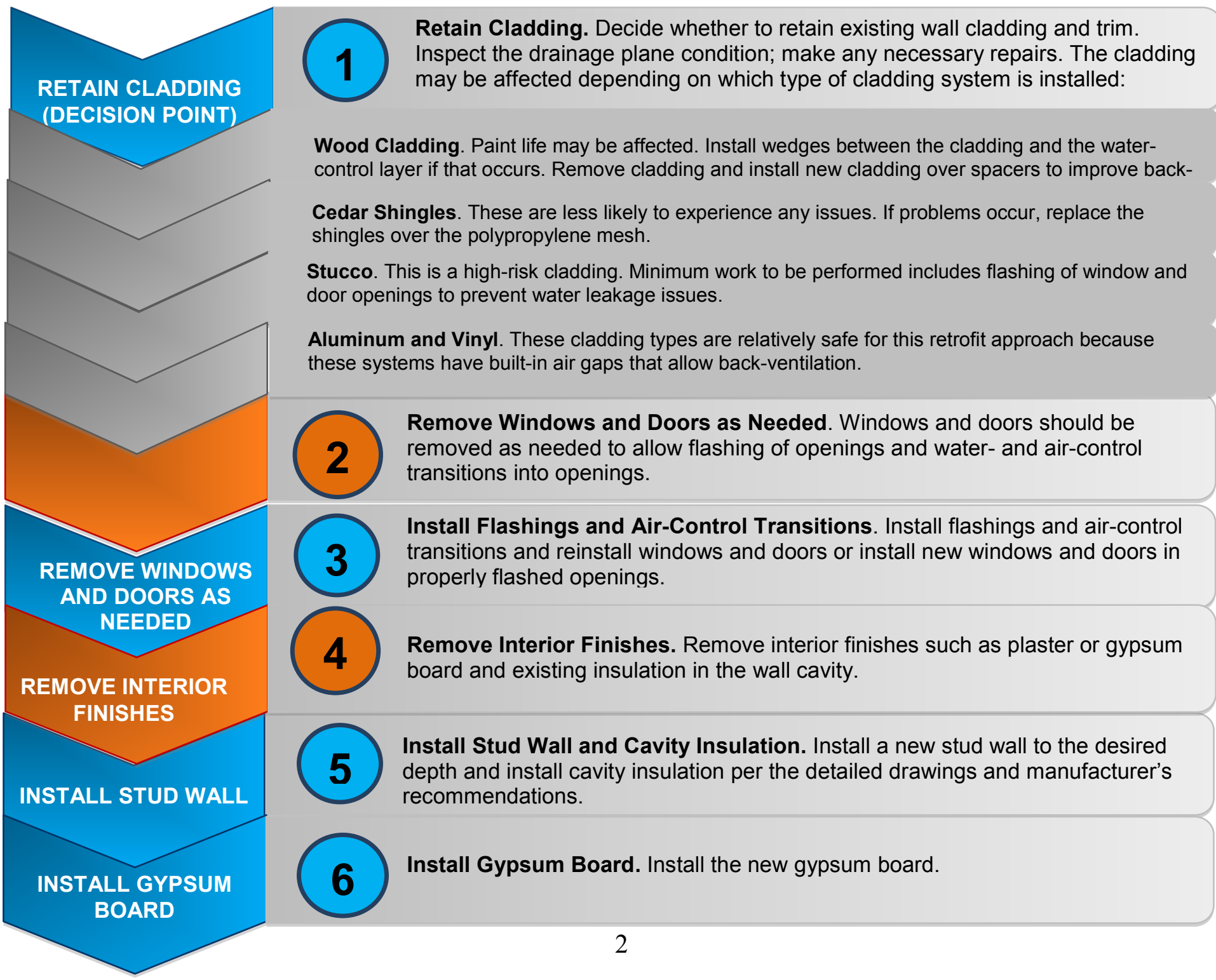




\section{Introduction}

This Measure Guideline describes a deep energy enclosure retrofit solution that involves insulation to the interior of the wall assembly with the use of a double-stud wall. The guide describes two approaches to retrofitting the existing the walls - one that involves replacing the existing cladding and the other that leaves the cladding in place. This guideline also discusses the design principles related to the use of various insulation types and provides strategies and procedures for implementing the double-stud wall retrofit. It also includes an evaluation of important moisture-related and indoor air quality measures that need to be implemented to achieve a durable high-performance wall.

An interior retrofit is typically less desirable than an exterior retrofit; exterior retrofits allow complete inspection and renovation of exterior moisture control detailing and layers. Interior retrofits are disruptive to the living space and the occupants; also, the interior double-stud wall reduces usable space. However, despite the advantages of exterior retrofits, many buildings must be retrofitted on the interior for reasons such as historic preservation, zoning or space restrictions, or aesthetics. The double-stud wall approach is also suitable if a full replacement of services within the exterior wall is planned.

An interior retrofit may or may not be less expensive, depending on such factors as access and whether a gut rehabilitation is planned. However, if an interior retrofit has been chosen, doublestud walls can be more cost-effective than exterior insulating sheathing. Double-stud walls insulated with cellulose or low-density open-cell spray polyurethane foam (ocSPF) can have Rvalues of 40 or higher. They have been used in high-performance housing since the 1970s; their advantages include trade familiarity with construction detailing (especially at the exterior) and the use of commonly available construction materials (Ueno 2014).

Double-stud walls have a higher risk of interior-sourced condensation moisture damage than do high-R approaches that use exterior insulating sheathing. Specific moisture control principles must be followed for a successful double-stud wall insulated retrofit. Controlling bulk water entry into the wall and maintaining certain levels of relative humidity $(\mathrm{RH})$ are vital to the success of the retrofit.

Loose-fill fibrous insulation, such as cellulose, is a common choice for double-stud walls because of its lower cost (in most markets). However, unlike spray foams, cellulose is an airpermeable insulation and increases moisture risks (Ueno 2014).

A lower risk approach involves spraying insulating foam in the entire double-stud wall cavity. Low-density, semipermeable ocSPF is a good choice; in monitored data, sheathing moisture contents are lower than those in cellulose walls.

Another assembly option is to combine spray foam with fibrous, air-permeable insulation (fiberglass or cellulose) to create a lower cost "hybrid" high-R wall assembly. The common name for this assembly is "flash and batt" (Maines 2011). High-density closed-cell spray polyurethane foam (ccSPF) is generally recommended for this application. The relative thickness of the foam layer is a function of wintertime condensation control in the local climate. 
This Measure Guideline is important to the high-performance retrofit industry because it demonstrates techniques for implementing interior double-stud walls in high-performance enclosure retrofits. The information is based on the latest research performed for the U.S. Department of Energy Building America program.

The U.S. Department of Energy's research Team Building Science Corporation wrote this guideline to support contractors who are implementing interior insulation high-performance enclosure retrofits and designers who want to design such retrofits. The Measure Guideline may also be helpful to building owners who wish to learn more about strategies available for deep energy enclosure retrofit of wood-framed residential buildings. 


\section{Decision-Making Criteria}

After issues such as aesthetics, historic significance, improved comfort, and the lifespan of the project are resolved, a retrofit can be chosen. This section discusses the major decision-making criteria for interior retrofits.

\subsection{Cost and Performance}

Cost and performance are intricately linked and have to be studied in combination to determine the best choice per the decision maker's goals and objectives. The decision about the thermal performance depends on the specific project requirements. For projects that aim to meet low energy use targets, a higher level of insulation must be provided.

The values provided in Table 1 illustrate costs for a 12-in.-deep double-stud wall; however, the depth varies depending on the project's thermal performance goals, budget, and acceptable square footage loss. Whether the wall is $12 \mathrm{in}$. deep or $8 \mathrm{in}$. deep, the cost of the new $2 \times 4$ stud wall at 16 in. on center is fixed; however, the benefit of higher insulation levels must be evaluated. The wall depth will also have an impact on the size of the living space; therefore, homeowners need to assess the tradeoff between providing a higher R-value in the wall and decreasing the size of the floor area. Another aspect is the cost of the interior finishes at the window wells; deeper walls will have higher trim costs. One way to reduce the cost of deeper window wells is to use gypsum for board jamb and head returns, as demonstrated by a New England-area high-performance builder (Ueno et al. 2013).

Table 1. Unit Costs for Double-Stud Wall Retrofit Components $\left(\$ / \mathrm{ft}^{2}\right)$ per RS Means

\begin{tabular}{c|c|c}
\hline Material Description & Nominal R-Value & Cost Range (\$/ft $\mathbf{~}^{\mathbf{2}}$ \\
\hline House Wrap & - & 0.33 \\
\hline $\mathbf{2} \times \mathbf{4}$ Wood Stud Wall @ 16 in. on center & - & 3.83 \\
\hline 12-in. Dense Pack Cellulose & 42 & 2.78 \\
\hline 12-in. Blown Fiberglass & 42 & 1.80 \\
\hline 12-in. Open-Cell Spray Foam (ocSPF) & 46 & 5.28 \\
\hline 4.5-in. Closed-Cell Spray Foam (ccSPF) & 27 & 3.97 \\
\hline 7.5-in. Dense Pack Cellulose & 26 & 1.52 \\
\hline 7.5-in. Blown Fiberglass & 26 & 1.07 \\
\hline 1/2-in. Gypsum Board (Level 4 Finish) & - & 1.60 \\
\hline
\end{tabular}

RSMeans Reed Construction Data 2013 (Reed 2013)

Installation costs for the retrofit solutions in this Measure Guideline can vary widely, depending on factors such as contractor experience, prevalent regional practices, material costs, and the particular circumstances of the project. Most cost values for the various wall components were obtained from RSMeans Cost Works 2013 (Reed Construction Data 2013), a cost-estimating tool that provides the costs of materials, installations, overhead, and profit. The values shown are for a project based in Boston, Massachusetts.

Other items such as cladding, cladding fasteners, spacers, self-adhered membrane flashings, and metal flashings are omitted from the table because use of the material varies based on individual projects. 


\subsection{Water Leakage Management}

Replacing (or not replacing) the cladding and the water membrane can have a significant effect on wall durability. Installing additional interior insulation (in the form of a double-stud wall) reduces heat flow through the wall, which then may not dry adequately. Therefore, previously survivable water leaks might cause long-term damage after the insulation retrofit (Lstiburek 2008b).

The decision about whether to replace the cladding should be evaluated based on the existing conditions and available project budget. One key assessment is to partially disassemble the wall to determine the presence and condition of the water-control membrane ("drainage plane"). If the drainage plane is not present or has deteriorated, the cladding should be replaced. The existing cladding should be carefully inspected to ensure that there are no active water leaks into the wall; this might be done by inspecting the exterior sheathing from the interior as part of the interior retrofit project.

Replacing the drainage plane and installing new cladding with an air gap (the "drained and ventilated cavity") greatly enhances the durability of the wall because it will drain better and dry more quickly and thoroughly (see Lstiburek 2013 for discussion and details). This measure is generally a prudent step in any double-stud insulation retrofit.

\subsection{Air Leakage Management}

Designing a retrofit that allows significant air leakage is risky; therefore, the air leakage performance of the retrofit strategies must be evaluated before a decision is made about whether to replace the cladding and the water- and air-control membrane. Experience has shown that air barrier systems can be formed by careful taping, caulking, and use of appropriate air sealing materials such as spray polyurethane products and fully adhered membranes. Of course, the materials must be properly installed using standard quality control measures.

\subsection{Constructibility}

The ease of construction might be a consideration depending on the decision maker's specific requirement. For projects in which the homeowners wish to perform the retrofit, options that involve low-tech construction techniques and are easier to implement might be worthwhile.

How easy (or difficult) a measure is to implement can greatly impact the success of a project. Difficult details and construction sequences often lead to increased cost and reduced performance. Efficiency in construction is driven by simple repeatable details and common construction practices. The more a measure deviates from common construction techniques (or requires complicated sequences that involve multiple trades), the more likely that the work will not have the intended result.

A key benefit of an interior double-stud wall with cavity insulation is that it does not significantly change standard construction practices and details (e.g., compared to an exterior rigid insulation wall). The installation of the water- and air-control membrane and cladding remains the same, with only a slight modification of adding ventilation spacers behind the cladding. The new nonload-bearing $2 \times 4$ stud wall inboard of the existing structural wall will have electrical and plumbing services installed per standard practice. The only difference is the interior finishes at the window wells. 


\section{Technical Description}

This section illustrates two approaches to retrofitting wood-framed buildings from the interior side with a double-stud wall:

1. Replace the existing cladding and the air- and water-control layer.

2. Retain the existing cladding and whichever water-control layer was previously installed.

\subsection{Double-Stud Wall Assembly: Replace Cladding}

The retrofit assembly for the first approach consists of new cladding installed over a spacer to provide an air gap between the cladding and the water- and air-control layer. Spacer options include $1 \mathrm{x}$ wood furring strips, a polypropylene mesh/drainage mat, vertical strips of insulating sheathing, and plastic manufactured spacer products (see Lstiburek 2010, 2012b for examples). Relatively low-profile ( $\sim 1 / 4$ in.) depth cladding spacers are commercially available that will reduce the impact of cladding connections to trim details.

A new water- and air-control membrane is installed over the existing wall sheathing in a shingle fashion. The membrane is extended into the window and door rough openings and wall penetrations are flashed into the membrane.

A new stud wall is installed inboard of the existing stud wall at the desired depth with new cavity insulation. The cavity insulation types appropriate for the retrofit include loose-fill fibrous insulation such as cellulose or fiberglass (Figure 1), ocSPF (Figure 2), and a hybrid approach using ccSPF with loose-fill fibrous insulation ("flash and batt" or "flash and fill," Figure 3).

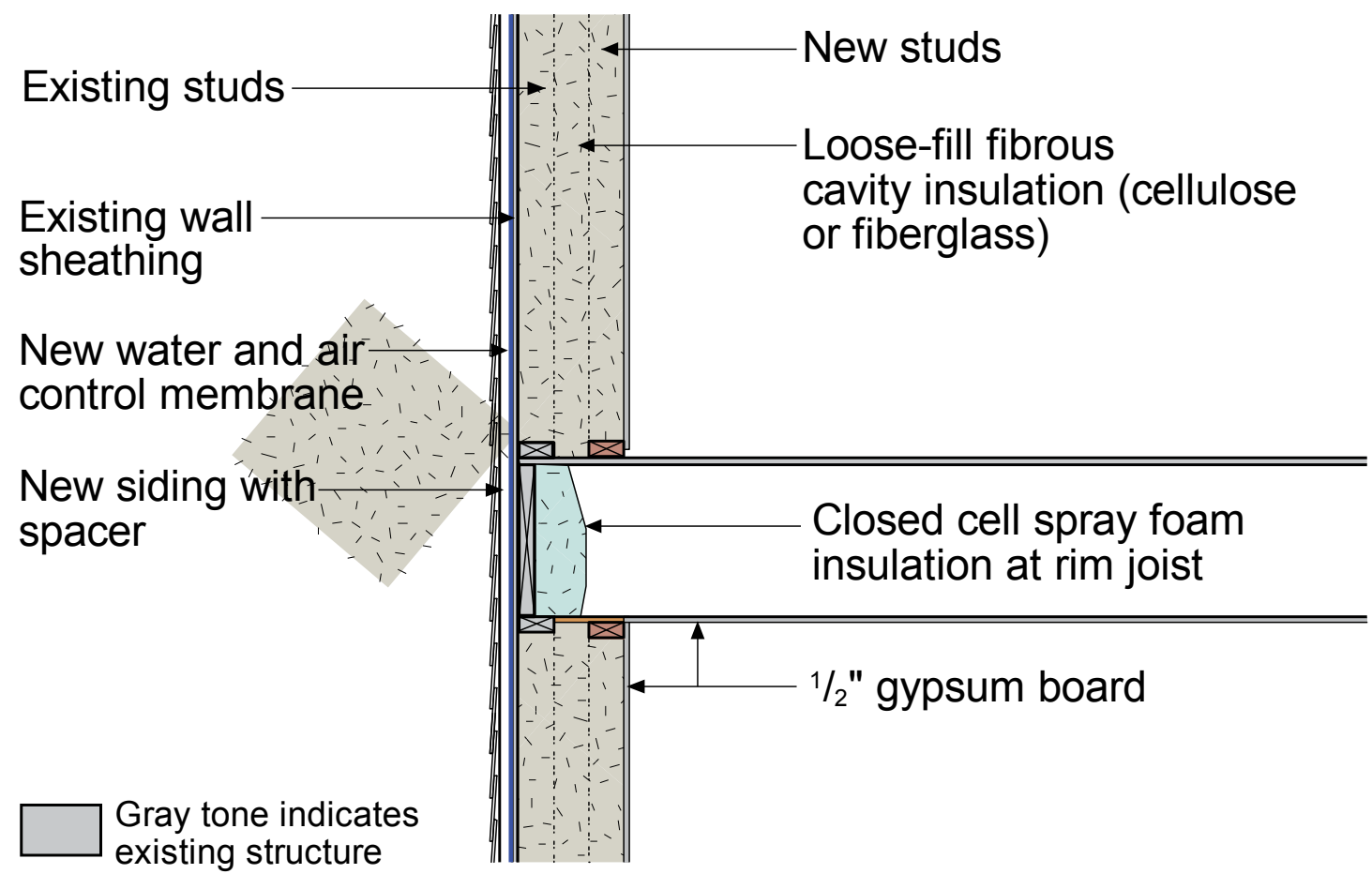

Figure 1. New cladding approach—double-stud wall with cellulose insulation 


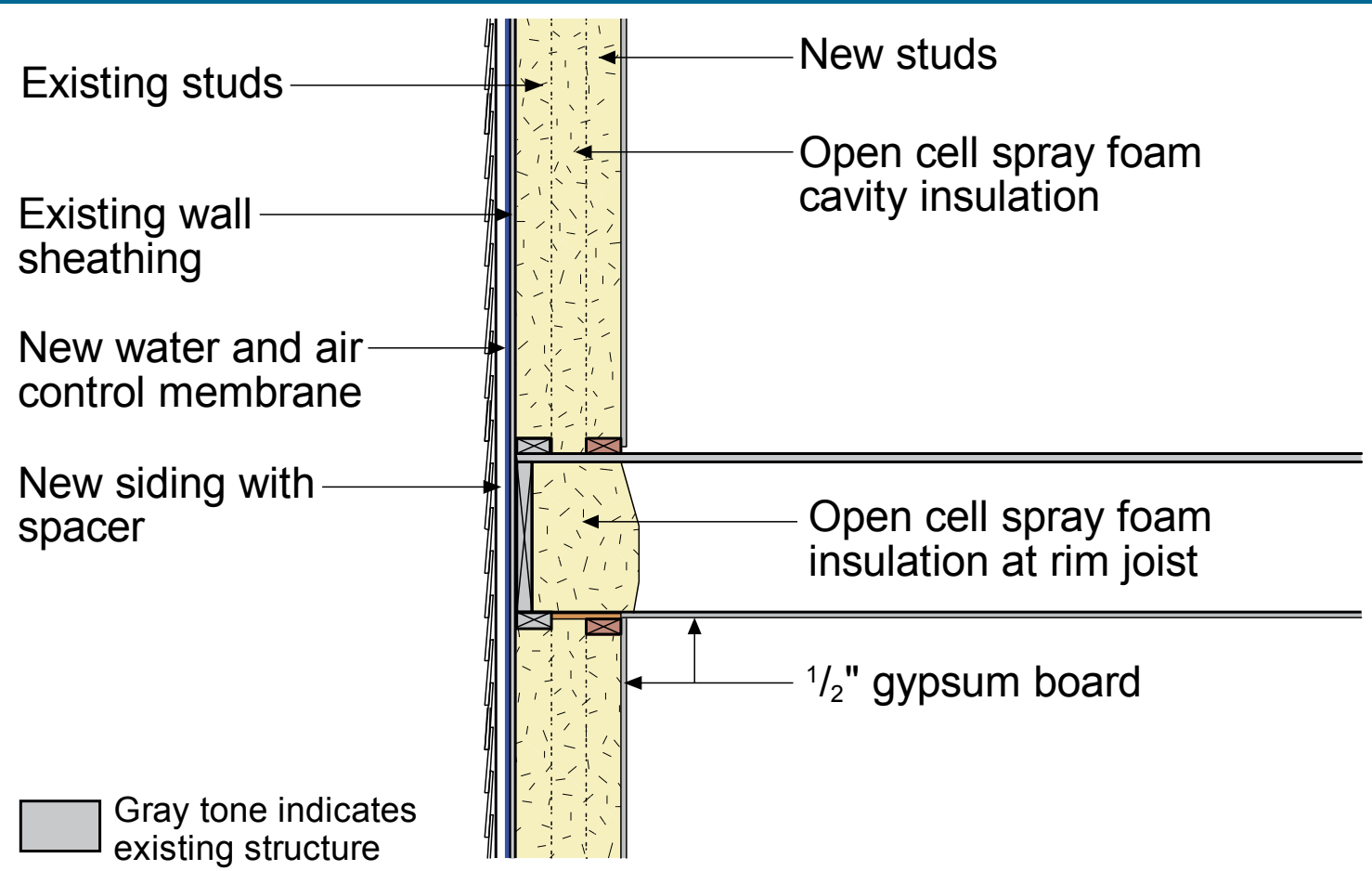

Figure 2. New cladding approach—double-stud wall with ocSPF insulation

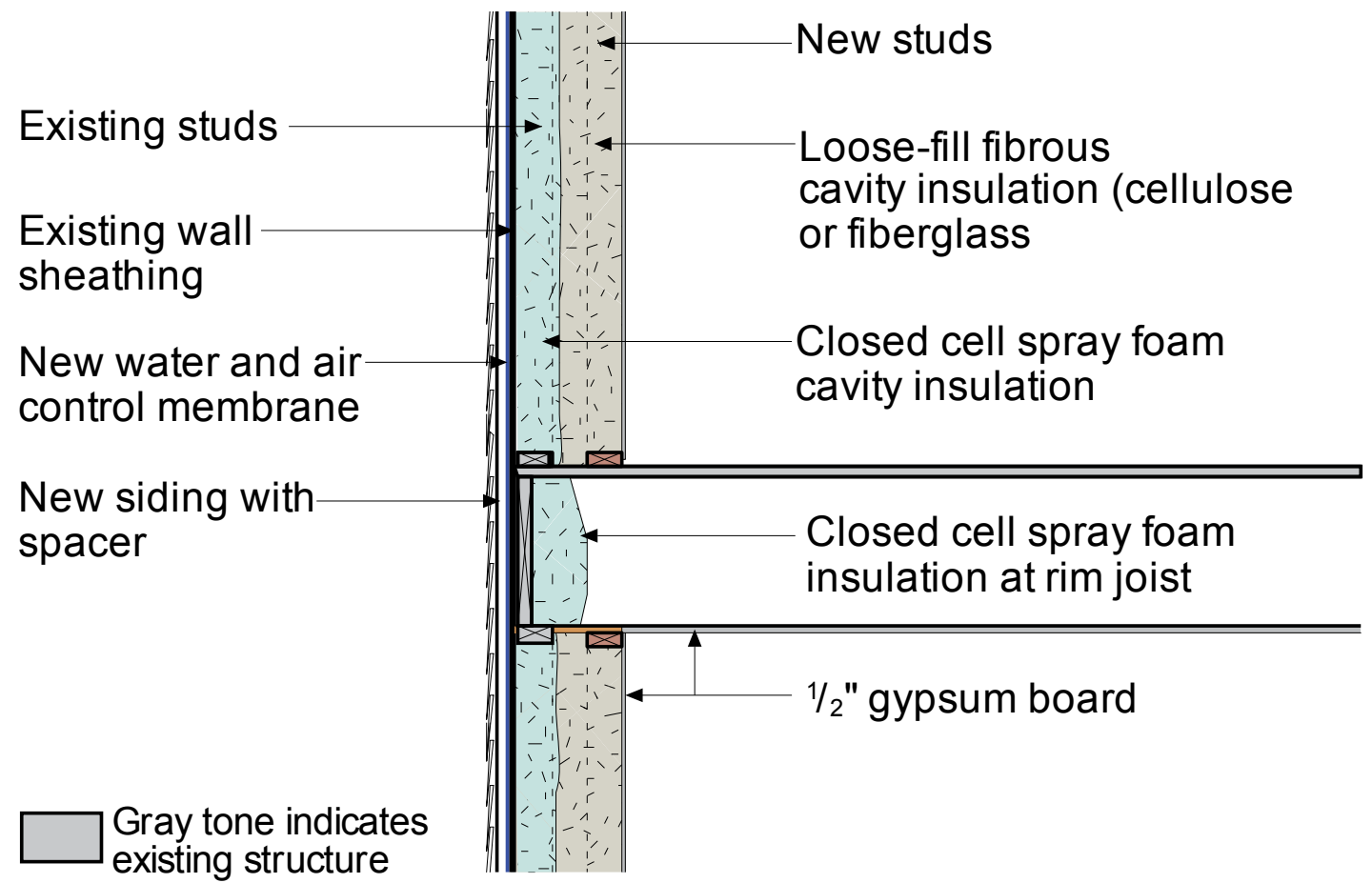

Figure 3. New cladding approach-double-stud wall with ccSPF and fibrous insulation

At the new (interior) wall top plate, a piece of plywood is installed to separate the wall cavity from the rim joist cavity. This is one way to provide a closed cavity for the blown-in loose fill insulation. This detail may be omitted at the ocSPF wall. 
The rim joist is shown insulated and air sealed with ocSPF or ccSPF for wintertime condensation control and to improve airtightness at this detail, which is composed of multiple framing members (see BSC 2009a, 2009b). If this detail is used, the "flash and batt" option might be more feasible, because a spray foam contractor may be onsite. The assembly is finished with new interior gypsum board.

\subsection{Double-Stud Wall Assembly: Retain Cladding}

The retrofit assembly for the second approach retains the existing cladding and connects the existing water- and air-control layer to the window and door rough openings (and wall penetrations) with self-adhered flashing. A new stud wall is installed inboard of the existing stud wall at a desired depth with new cavity insulation. Cavity insulation types that are appropriate for the retrofit include ocSPF (Figure 4) and a hybrid approach that uses ccSPF with loose-fill fibrous insulation such as cellulose or fiberglass (Figure 5). The assembly is finished with new gypsum board.

Double-stud walls reduce energy flow through the assembly; thus, the walls dry more slowly. One way to compensate for this reduced drying is to put an air gap between the cladding and the water-control layer to provide drainage, water redistribution, and drying (see Lstiburek 2010). However, when the cladding is retained, it is unlikely to have the recommended air gap. As discussed earlier, the exterior walls should be inspected for the presence and condition of the water-control layer or drainage plane to find water leakage issues. The walls may also need to be inspected - and even demolished — from the interior.

Impacts on various cladding systems and recommended approaches follow:

- Wood clapboards - a disadvantage of this method may be shortened paint life on the wood siding. If this occurs, siding wedges between clapboards may improve ventilation between the cladding and the water-control layer. If wedges do not improve the backventing, the cladding should be replaced and installed over spacers.

- Cedar shingles - this type of cladding is less likely to experience any issues. If it does, however, the shingles should be replaced and installed over a polypropylene mesh.

- Stucco - this is a high-risk cladding because it is an airtight system. The minimum work that should be performed includes flashing of the window and door openings (and any wall penetrations) to prevent water leakage issues. Risks associated with stucco are discussed by Lstiburek (2008a).

- Aluminum or vinyl - these cladding types are relatively safe for this retrofit approach because these systems have built-in air gaps that allow back-ventilation. 


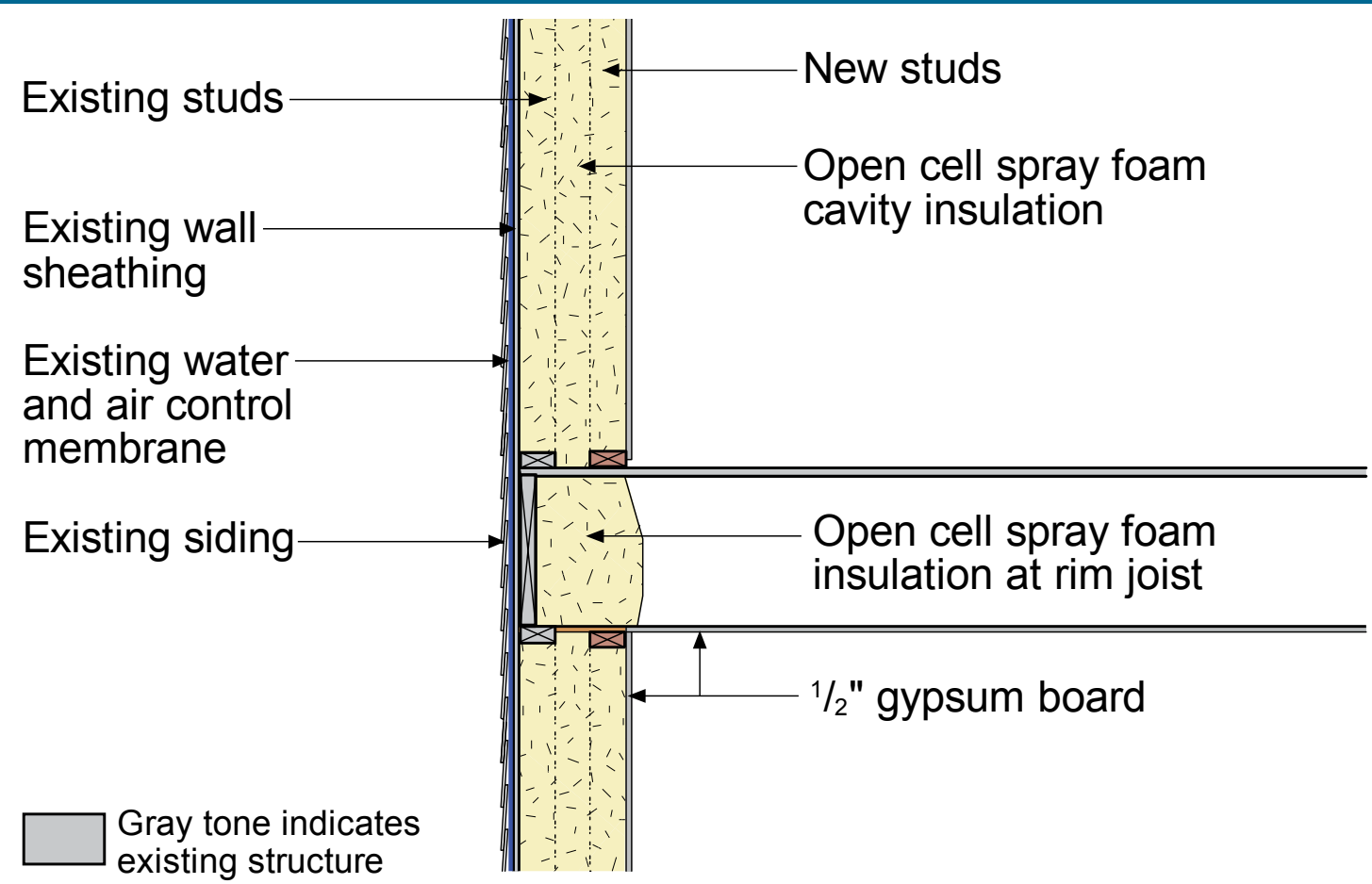

Figure 4. Existing cladding approach—double-stud wall with ocSPF insulation

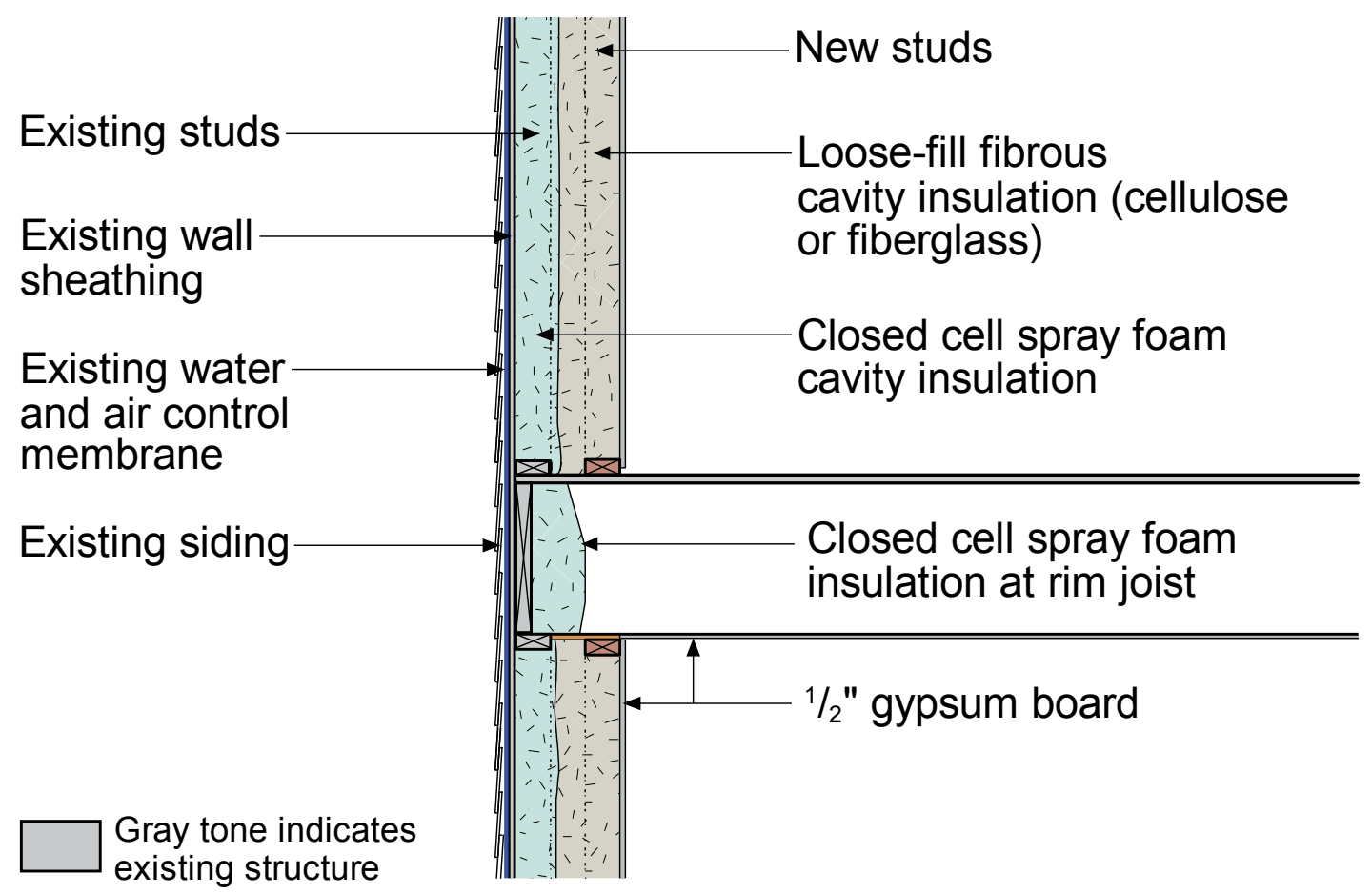

Figure 5. Existing cladding approach-double-stud wall with ccSPF and fibrous insulation 


\subsection{Water-Control Layer}

Controlling bulk water entry when performing interior wall retrofits is vital to the project's success because the increased insulation reduces drying. In most walls, a water-control layer protects the structure. Water-control layers are water-repellent materials (building paper, house wrap, sheet membranes, liquid-applied coatings, or taped and sealed rigid insulation boards) that are located behind the cladding and are designed and constructed to drain water that passes through the cladding. They are interconnected with flashings at window and door openings (and other penetrations) to drain water out of the assembly. The materials that form the water-control layer overlap each other in shingle fashion or are sealed so that water drains down and out of the wall (see Figure 6). The water-control layer is often referred to as the drainage plane, the waterresistant barrier, or water-control layer.

For the water-control layer to be effective, water must drain downward and outward from behind the cladding. The "out" direction is typically provided by flashings (see Figure 6, left). Flashings are the most underrated — and arguably the most important—-building enclosure component. Flashings are integrated with water-control layers (see Figure 6, right).
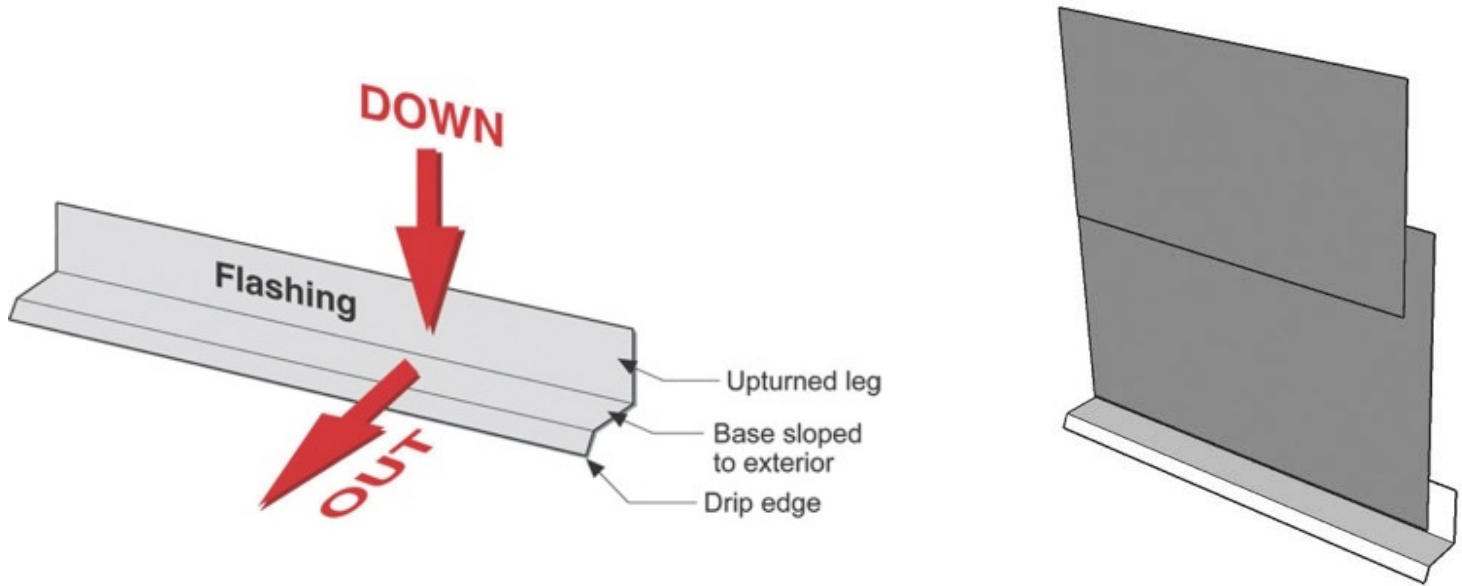

Figure 6. The "down" and "out" approach to flashing (left); flashing integrated with the water-control layer with lapped joints (right)

All windows should be installed in a pan-flashed and drained opening, with the jambs and head of the frame taped or sealed to the wall water-control layer. (See Figure 7 and Figure 8 for the head and sill window details for both approaches.) 


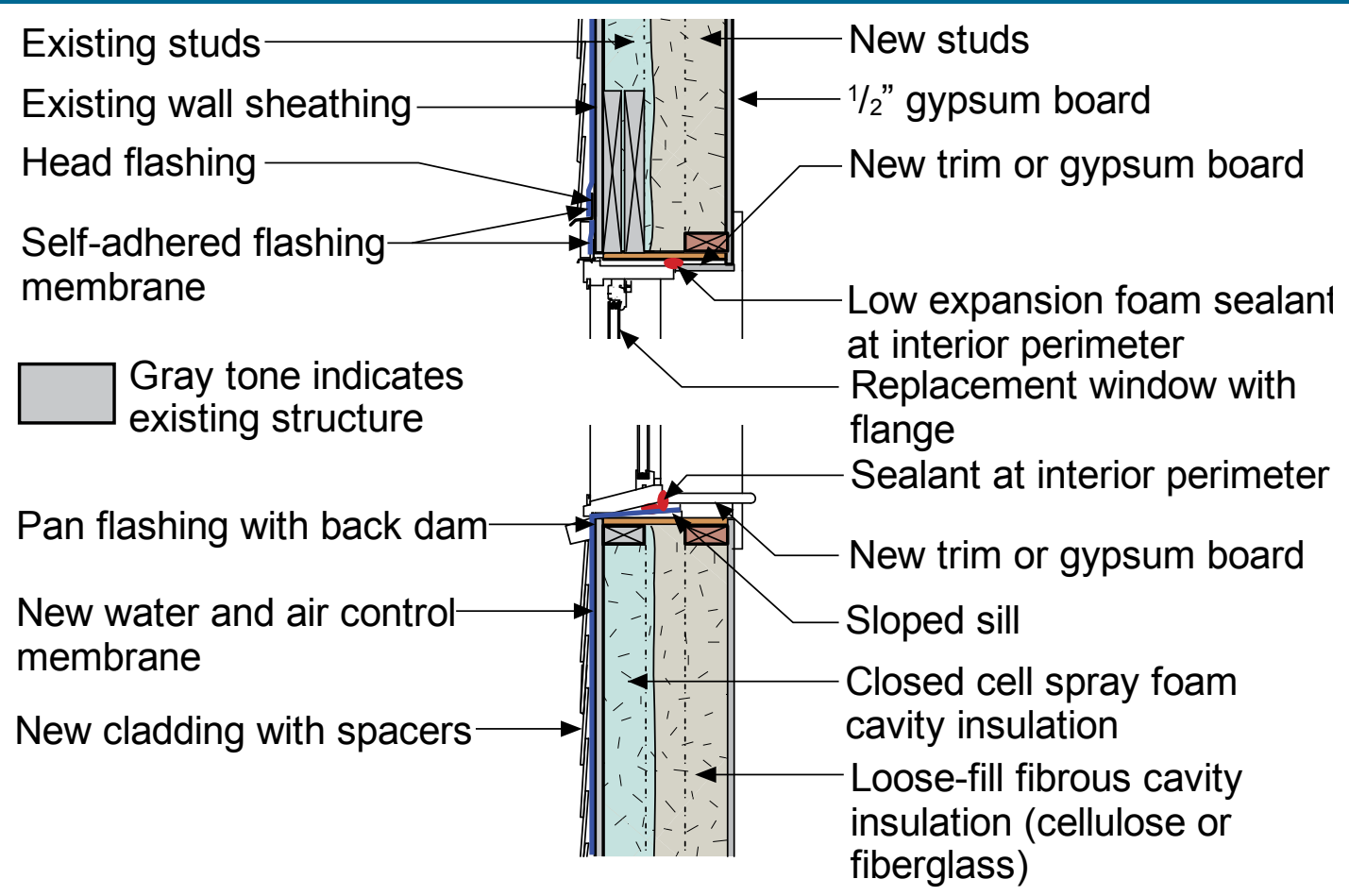

Figure 7. Head and sill window detail at double-stud wall with new cladding

In the second retrofit approach (existing cladding and air- and water-control layer left in place, not upgraded), at a minimum, window and door rough openings must be properly flashed into the existing water-control layer.

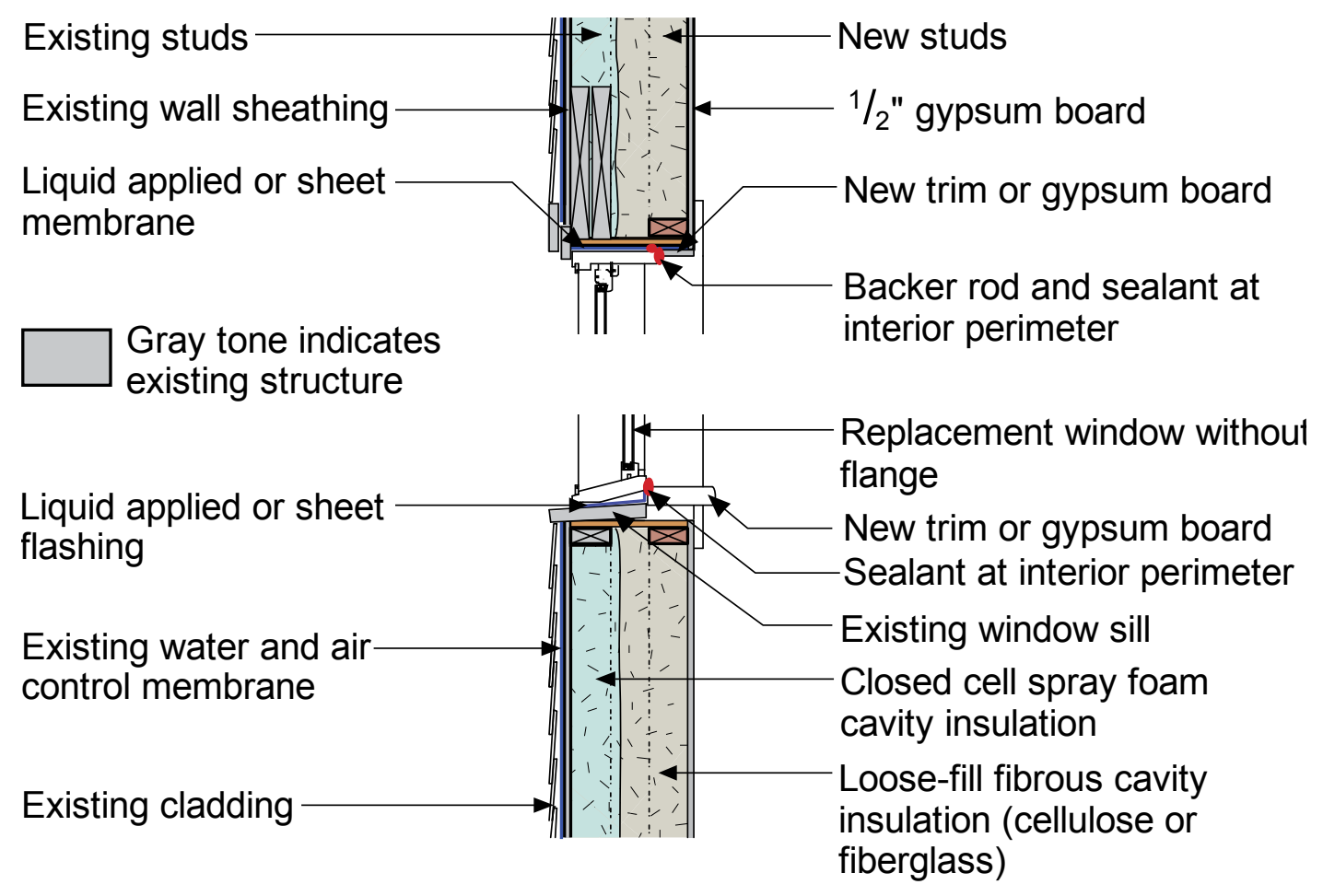

Figure 8. Head and sill window detail at double-stud wall with existing cladding 
This option is dependent on the quality of the existing water-control detailing of the cladding; if the basic flashing details are not present (window head flashings, step flashings at the roof-towall interface, and kickout flashings at roof-to-wall interfaces), they should be added. Guidance can be found in Lstiburek (2006 and 2012a).

\subsection{Air-Control Layer}

Controlling airflow in a

building enclosure is

important because it

influences heat and

moisture flow. A key

strategy in the control of

Air-control layers are required to resist the air pressure differences that act on them. Rigid materials such as gypsum board, and exterior sheathing materials such as plywood, oriented strand board, or rigid insulation are particularly well suited to act as air control layers. Many flexible materials such as house wraps, sheet polyethylene, fully adhered membranes, and liquid applied membranes typically need to be coupled with a rigid material to be effective. airflow is the use of air-control layers. These layers are systems of materials that are designed and constructed to control airflow between a conditioned space and an unconditioned space. The air-control layer is the primary air enclosure boundary that separates indoor (conditioned) air from outdoor (unconditioned) air (Lstiburek 2006).
CODE REQUIREMENTS FOR

AIR LEAKAGE ARE FOUND IN

SECTION 402.4 OF THE 2009 IECC

AND R402.4 OF THE 2012 IECC.

Air-control layers can be located anywhere in the wall assembly - at the exterior surface, the interior surface, or at any location between. Depending on the climate or wall configuration, aircontrol layers might be required to address airflow through the enclosure assembly and to control airflow into or within the enclosure assembly (Lstiburek 2006).

In this interior retrofit, the water- and air-control membrane was used to place the air-control layer over the existing wall sheathing. If the cavity insulation chosen for the retrofit involves either ocSPF or ccSPF with loose-fill fibrous insulation, the spray foam insulation provides additional airtightness to the assembly.

The wall design should also control the airflow into the stud space from the interior to control air leakage condensation. One interior air barrier approach is the airtight drywall approach; see Lstiburek (2006) and BSC (2009a, 2009b) for further details. In addition to taping the drywall seams, the airtight drywall approach also requires Air-control layers should be:

1. Impermeable to airflow

2. Continuous over the entire building enclosure

3. Able to withstand the forces that may act on them during and after construction

4. Durable over the expected lifetime of the building. that the drywall edges be sealed to solid framing materials by applying a continuous bead of sealant to all exterior wall bottom and top plates, all top plates at insulated ceilings, rough opening perimeters, and both sides of the first interior stud of partition walls.

Increasing the building airtightness (which would result from this interior retrofit) can cause indoor air quality problems; mechanical ventilation, pollution source control, and combustion safety measures must be implemented to manage this risk. 


\subsection{Vapor-Control Layer (Principles)}

The fundamental principle of a vapor-control layer is to keep water vapor out of an assembly and to let water vapor out if it gets in. In this regard, the vapor-control layer is really more of a vaporcontrol "strategy" that uses materials with specific vapor-control properties within the assembly. Water vapor control can become complicated because sometimes the best strategies to keep the vapor out also trap the vapor in.

Vapor-control layers installed on the interiors of assemblies prevent assemblies from drying inward. This is a concern in any air-conditioned building or in any building that also has a vaporcontrol layer on the exterior. It's the "double vapor barrier" problem, which occurs when moisture within the assembly cannot dry to either side. This moisture could come from assemblies that start out wet because of rain, or because wet materials were used during construction without being allowed sufficient time to dry before being closed in. More importantly, imperfections in the water-control layer can cause rain leakage inside the assembly; if there is no drying to either side, continued wetting can lead to assembly failure.

The three principal control approaches to dealing with water in vapor form are:

1. Let the water vapor pass through the assembly from the inside out and from the outside in. A wall assembly can dry to both sides. This is called a flow-through assembly.

2. Locate a distinctive vapor-control layer to retard the flow of water vapor into the wall assembly from either the inside or the outside. This is called a vapor-control layer assembly. The most common location for a vapor-control layer is on the inside ("warm in winter" side) of the thermal insulation (typically for cold climates).

3. Raise the surface temperature with insulation to control the temperature of the surfaces where condensation is likely. This is most commonly done by using rigid insulation on the exterior of assemblies. This is called control of condensing surface temperature assembly.

\subsection{Vapor-Control Layer (Assemblies)}

Fibrous Insulation (Vapor-Control Layer Option): One option is to fill the entire wall cavity with loose-fill fibrous insulation such as cellulose or fiberglass (see Figure 1). However, these insulation materials are air-permeable and highly vapor permeable. Therefore, some type of interior vapor control is required in cold climates to ensure that vapor diffusion does not cause condensation on (or damaging moisture accumulation in) moisture-sensitive materials. Table 2 lists the vapor retarder classes as shown in the 2009 and 2012 International Residential Code (IRC) (ICC 2009a, 2012a).

Table 2. Vapor Retarder Classes (2009 IRC and 2012 IRC)

\begin{tabular}{c|c}
\hline Class & Permeability \\
\hline Class I & 0.1 perm or less \\
Class II & 1.0 perm or less and greater than 0.1 perm \\
Class III & 10 perm or less and greater than 1.0 perm \\
\hline
\end{tabular}

Ueno (2014) studied cellulose- and ocSPF-insulated double-stud walls in field monitoring in Massachusetts/zone 5A. He found that in a cellulose wall, the use of a Class III (latex paint) 
vapor retarder during high interior $\mathrm{RH}$ conditions $(40 \%-50 \%)$ in wintertime resulted in very high sheathing moisture contents and liquid water condensation (at the sheathing-insulation interface). He recommended that a Class II vapor retarder (e.g., variable permeability membrane or vapor retarder paint) be used to reduce these high moisture levels. A Class I vapor retarder (polyethylene) was not recommended because it completely eliminates inward drying. This option has some risk because control of air leakage condensation is dependent on the workmanship of the interior air barrier; high-density fibrous fill insulations (e.g., dense-pack cellulose) may reduce — but do not completely eliminate — these risks.

ocSPF Insulation (Vapor-Control Layer Option): Another insulation option is to fill the entire wall cavity with ocSPF (see Figure 2 and Figure 4). Ueno's (2014) measurements of ocSPF double-stud walls indicated less moisture accumulation than in the cellulose walls. The ocSPF material provides reasonable vapor control at the thicknesses applied ( 2.0 to 2.5 perms in 12 in.; lower end of Class III). Therefore, it is a marginal judgment call whether a Class II vapor retarder is needed or warranted; its use would definitely be conservative, but quite likely unnecessary. This assembly may be lower risk than the cellulose with vapor-control layer option.

"Hybrid" Insulation (Control of Condensing Surface Temperature Option): Another insulation option is to combine loose-fill fibrous insulation with ccSPF on the outboard side of the cavity (hybrid wall; see Figure 3 and Figure 5). The high-density ccSPF is an airimpermeable layer, so any wintertime condensation (from an interior source) would occur at its inboard side. The ccSPF prevents condensation by warming the temperature of the potential condensing surface. In colder climates, a sufficient ratio of vapor-impermeable insulation (ccSPF) to total wall assembly insulation must be maintained. As the outdoor temperature falls, the amount of insulation needed to maintain the sheathing temperature increases.

Table 3 provides guidance for the insulation ratios. The table presents information taken from Table R601.3.1 Class III Vapor Retarders of the 2009 IRC (ICC 2009a) and Table R702.7.1 Class III Vapor Retarders of the 2012 IRC (ICC 2009b). Table 3 shows values for minimum thermal resistance to control condensation using exterior insulating sheathing for climate zones 5-8 and marine 4. The percentage of the total insulation that is exterior (e.g., insulating sheathing and spray foam insulation) is also shown. These percentages can be used to calculate R-value ratios for ccSPF versus fibrous fill in hybrid double-stud walls.

Table 3. Thermal Resistance Values To Control Condensation Using Exterior Insulating Sheathing for Climate Zones 5, 6, 7, 8, and Marine 4 From (2009 IRC and 2012 IRC)

\begin{tabular}{c|c|c|c}
\hline Climate Zone & $\begin{array}{c}\text { Minimum R- } \\
\text { Value }(\mathbf{2} \times \mathbf{4})\end{array}$ & $\begin{array}{c}\text { Minimum R- } \\
\text { Value }(\mathbf{2} \times \mathbf{6})\end{array}$ & $\begin{array}{c}\text { \% Exterior } \\
\text { Insulation }( \pm)\end{array}$ \\
\hline $\mathbf{4 C}$ & 2.5 & 3.75 & $16 \%$ \\
$\mathbf{5}$ & 5 & 7.5 & $28 \%$ \\
$\mathbf{6}$ & 7.5 & 11.25 & $37 \%$ \\
$\mathbf{7 / 8}$ & 10 & 15 & $44 \%$ \\
\hline
\end{tabular}

A Class III vapor retarder (latex paint) would then be used on the interior of the wall. Overall, this assembly has a very low risk provided that proper ratios of insulation are used. 
More detailed analysis could be conducted to optimize the assembly; hygrothermal modeling, when used appropriately, would provide the most refined analysis of the risk. However, analysis at this level is seldom required for residential construction. Other methods such as a dew point calculation that looks to limit the sheathing temperature to $45^{\circ} \mathrm{F}$ based on the average temperature over the coldest 3 months of the year

CODE REQUIREMENTS FOR

THERMAL INSULATION ARE FOUND

IN SECTION 402 OF THE 2009 IECC

AND R402 OF THE 2012 IECC. (assumed interior conditions of $35 \% \mathrm{RH}$ and $70^{\circ} \mathrm{F}$ ) is a reasonable check against condensation risks. These methods are discussed by Lstiburek (2006) and Straube (2011).

\subsection{Thermal Control Layer}

The function of the thermal control layer is to control the flow of heat from both the inside to the outside and from the outside to the inside. As with the other control layers, the most important factor to consider when dealing with the thermal control layer is its continuity.

The amount of cavity insulation added to the assembly will be dependent on the climate zone and design goals for the project. The minimum levels should be based on the minimum requirements for vapor control (see previous section) and minimum requirements based on the current adopted building code and energy code, respectively, for the project. Additional insulation can be installed above these minimums to create high R-value wall assemblies.

Table 4 provides the minimum thermal resistance (R-value) requirements for framed walls specified in the 2009 IECC (ICC 2009b) and the 2012 IECC (ICC 2012b) based on climate zone.

Table 4. Recommended Minimum R-Value for Wall Enclosures

\begin{tabular}{c|c|c}
\hline & \multicolumn{2}{|c}{ Framed Wall Minimum R-Value } \\
\hline Climate Zone & $\mathbf{2 0 0 9}$ IECC $^{*}$ & 2012 IECC \\
\hline $\mathbf{1}$ & 13 & 13 \\
\hline $\mathbf{3}$ & 13 & 13 \\
\hline $\mathbf{4}$ Except Marine & 13 & 20 or $13+5$ \\
\hline $\mathbf{5}$ and Marine 4 & 13 & 20 or $13+5$ \\
$\mathbf{6}$ & 20 or $13+5$ & 20 or $13+5$ \\
\hline $\mathbf{7}$ and 8 & 20 or $13+5$ & $20+5$ or $13+10$ \\
\hline
\end{tabular}

* International Energy Conservation Code

\subsection{Climate Zones and Building Environments}

Buildings should be suited to their environment. Building enclosures should be designed for a specific hygrothermal region (Figure 10), rain exposure zone (Figure 11), and interior climate.

For most residential buildings, interiors are assumed to be conditioned to about $70^{\circ} \mathrm{F}$ in the winter and $75^{\circ} \mathrm{F}$ in the summer. RHs should be no higher than $35 \%$ during the coldest month in winter and no higher than $65 \%$ in the summer. 
These conditions also form the basis for the requirements delineated in the model building codes. The model building codes climate zones referenced in the 2009 IECC and the 2012 IECC can be seen in Figure 9.

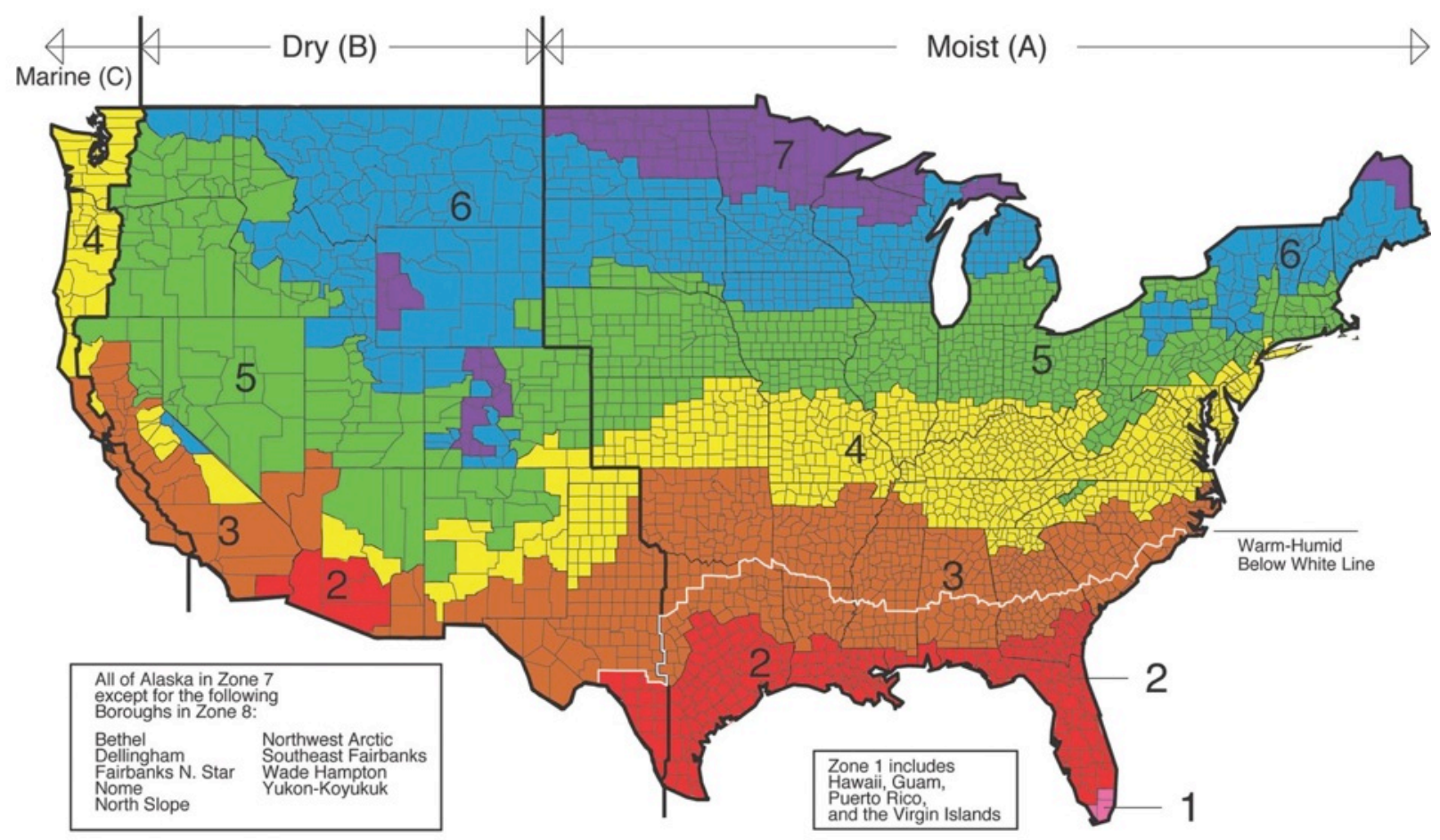

Figure 9. U.S. Department of Energy climate zones 


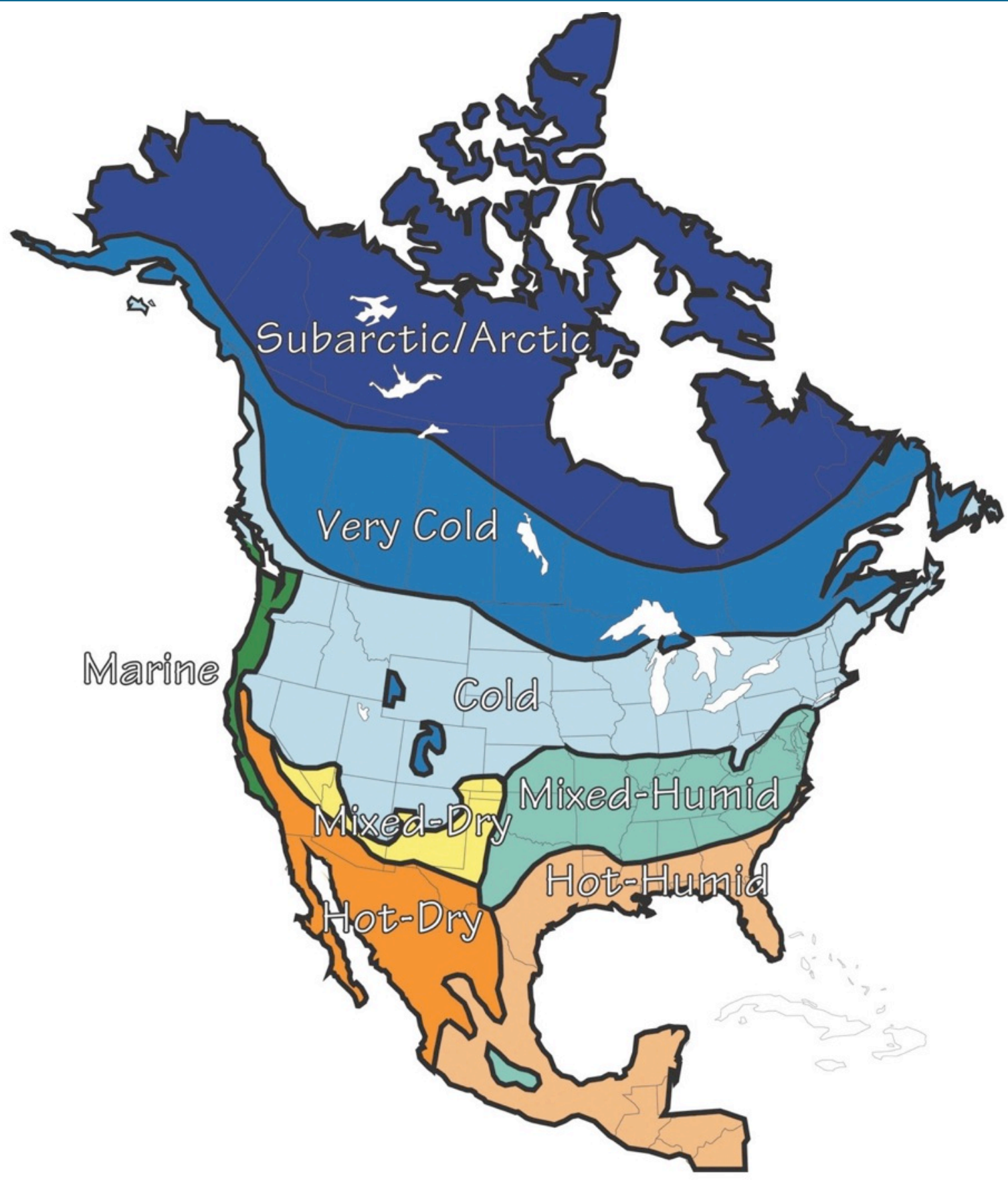

Figure 10. Hygrothermal map, Lstiburek 2006 


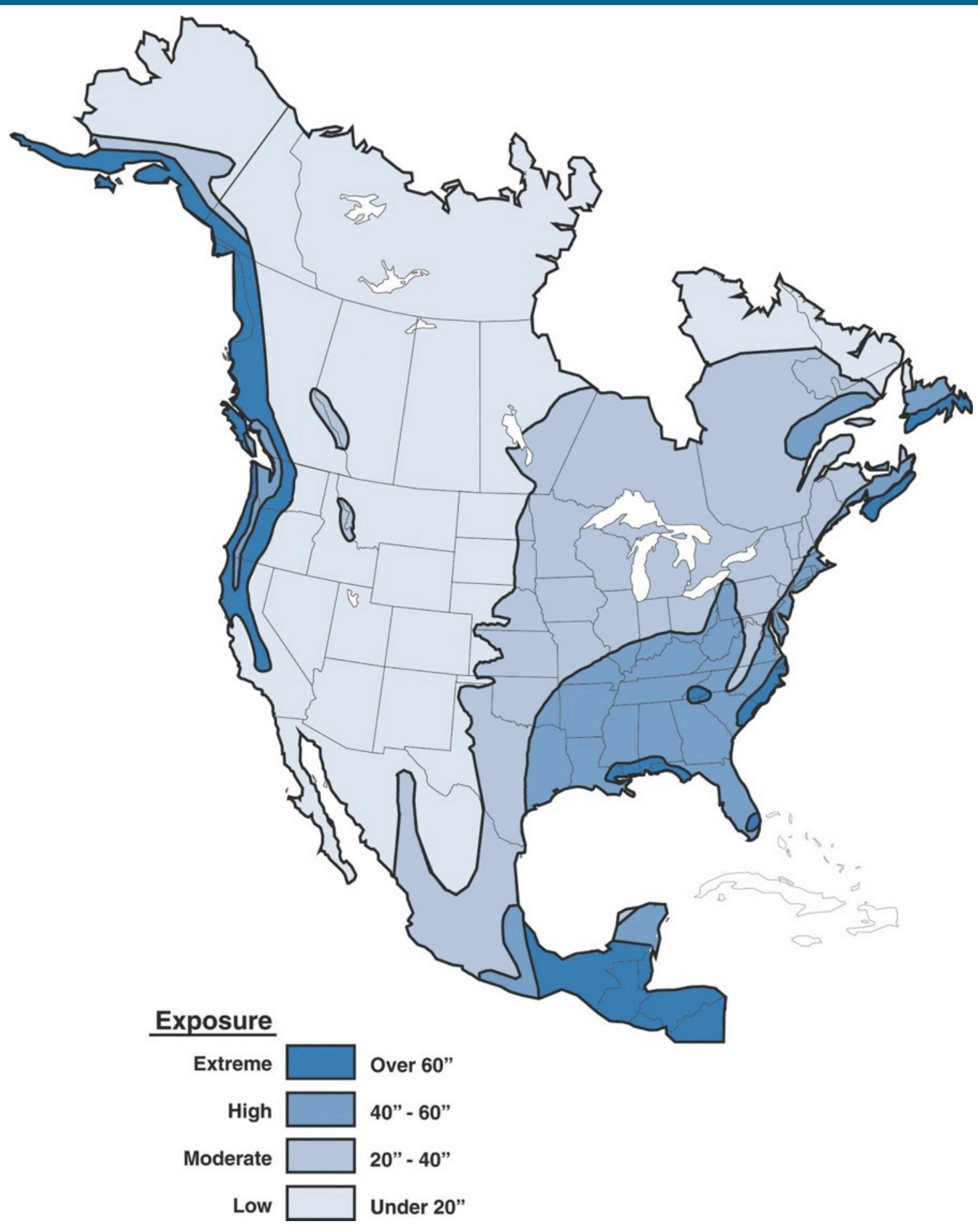

Figure 11. Rainfall map, Lstiburek 2006 


\section{Measure Implementation}

\subsection{New Cladding Option}

\section{Scope of Work}
A. Remove the existing wall cladding and trim. Prepare the wall sheathing for the water- and air-control membrane.
B. Remove windows and doors as needed to allow flashing of openings and water- and air- control transitions into openings.
C. Install a continuous water- and air-control membrane over the existing wall sheathing. Transition the wall water- and air-control membrane to adjacent assemblies.
D. Install flashings and air-control transitions and reinstall windows and doors or install new windows and doors in properly flashed openings.
E. Install new wall cladding and trim over spacers to provide an air gap.
F. Remove interior finishes such as plaster or gypsum board and existing insulation in the wall cavity.
G. Install a new stud wall and cavity insulation.
H. Install the gypsum board.

\subsection{Existing Cladding Option}

\section{Scope of Work}

A. Retain the existing wall cladding and trim. Cladding may be affected depending on which type of cladding system is installed.

B. Remove windows and doors as needed to allow flashing of openings and water- and aircontrol transitions into openings.

C. Install flashings and air control transitions and reinstall windows and doors or install new windows and doors in properly flashed openings.

D. Remove interior finishes such as plaster or gypsum board and existing insulation in the wall cavity.

E. Install a new stud wall and cavity insulation.

F. Install the gypsum board.

\subsection{Climate-Specific Factors}

The building enclosures should be designed for a specific hygrothermal region and are dependent on the design goals for the project. The assemblies should follow the minimum requirements based on the current adopted building code and energy code, respectively, for the project.

\subsection{Field Inspection}

Identify and address risks to occupants or the building that could be aggravated by the work. Verify safe working conditions. Determine whether the building has more urgent problems that must be addressed. Determine the feasibility of the retrofit solution and of options. 
Inspect and assess the building for:

- Structural integrity of house framing

- Hazardous materials (e.g., lead, radon, or asbestos)

- Safety and serviceability of the electrical system

- Rainwater or plumbing water leaks

- Rot or decay in framing

- Insect and pest damage and activity.

Deficiencies or hazards must be remediated before the project begins or remediation must be incorporated into the scope of the project.

Identify any atmospherically vented (or naturally aspirated) combustion appliances in the home. With the exception of gas stoves and cooktops, combustion appliances - including fireplacesshould be direct-vented or direct exhaust-vented equipment. Atmospherically vented appliances must be replaced or reconfigured to direct-vented or direct exhaust-vented operation before the project begins or as part of the project scope.

Verify that all kitchen and bathroom exhausts are vented to the exterior of the building. Source control ventilation deficiencies must be corrected either before the project begins or as part of the project.

If the home lacks a ventilation system that meets the requirements of the 2012 International Residential Code (2012 IRC, ICC 2012a), Section M1507.3 (or other relevant ventilation standards such as ASHRAE 62.2), a ventilation system meeting this requirement must be installed either before the project begins or as part of the project.

\subsection{Implementation Risks}

Construction and renovation work entails inherent risks to workers. All applicable safety procedures must be followed.

\subsection{Installation Procedure for New Cladding Option}

A. Remove existing wall cladding and trim; prepare wall sheathing for waterand air-control membrane

Removal of siding and trim is a well-established procedure; proper safety measures (e.g., lead paint control) should be undertaken as needed. Cladding in good condition may be reused; however, cladding that is being replaced has quite likely reached the end of its service life.

Appropriate preparation of the wall sheathing will depend upon the condition of the existing sheathing and the air-control strategy. If a sheet good is used as the air- and water-control layer, all protruding fasteners must be removed to avoid punctures or tears in the membrane. Gaps or voids in the sheathing layer may need to be filled; manufacturers' installation directions provide guidance. 


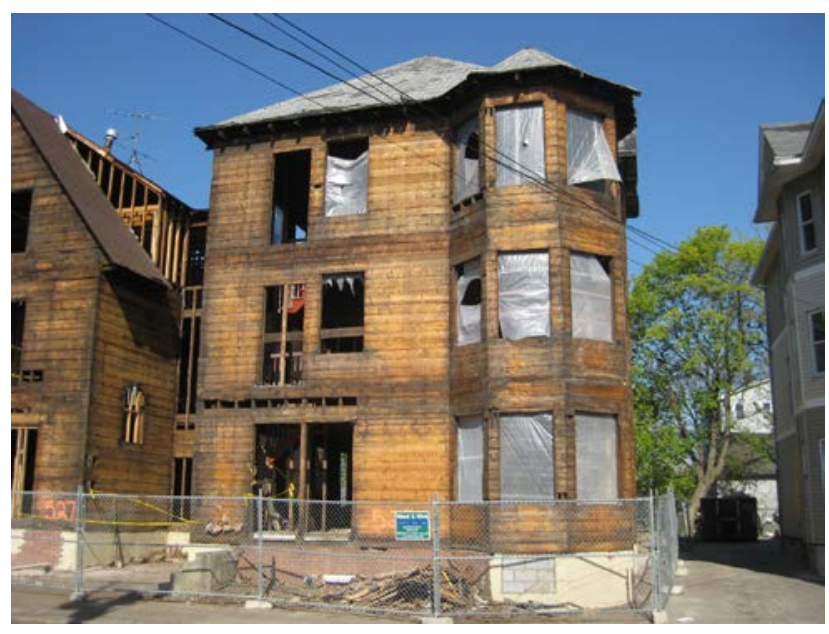

Figure 12. Exterior finishes are removed and existing wall sheathing is exposed.

\section{B. Remove windows and doors as needed}

Typically the windows and doors must be removed to allow proper flashing of the window and door openings and to permit the installation of air-control transition membranes.

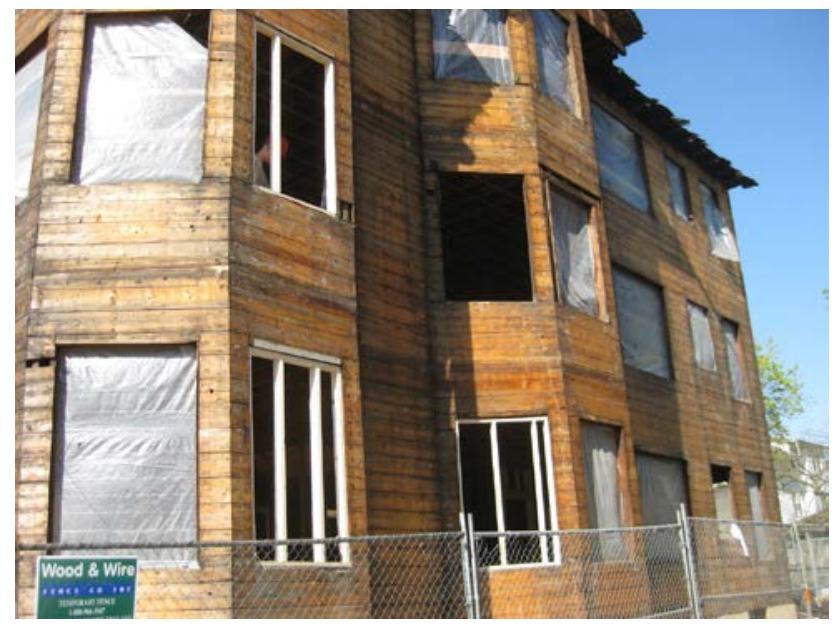

Figure 13. Windows and doors are removed.

\section{Install water- and air-control membrane}

Install a continuous water- and air-control membrane over the existing wall sheathing. Connect the membrane to the water- and air-control layer of the adjacent assemblies (roofs, foundations, etc.) in a watertight and airtight manner. Seal all penetrations against water and air leaks.

Ensure that the water- and air-control membrane is vapor permeable or vapor open (see Section 3). 


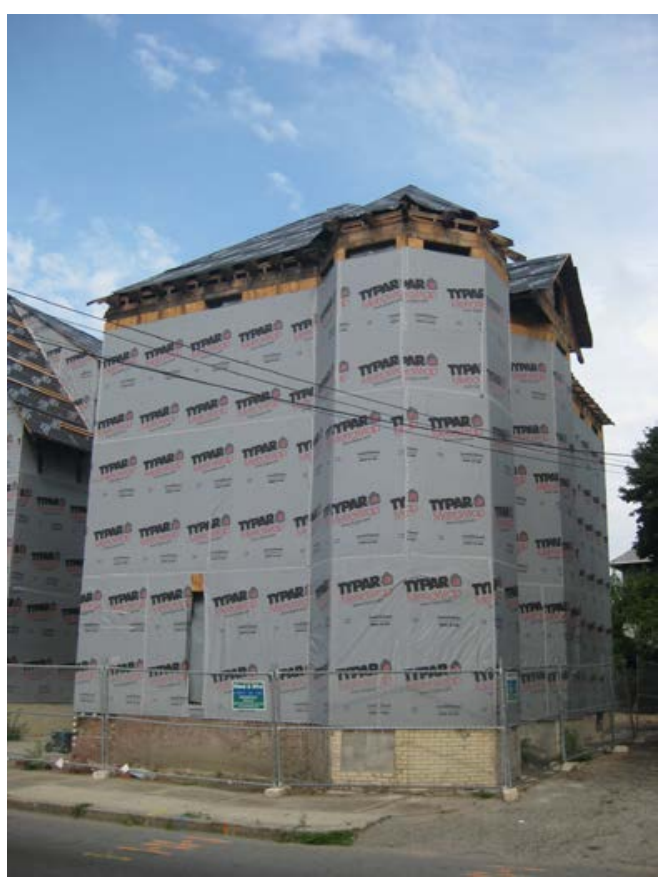

Figure 14. Water- and air-control membrane is in place.

D. Install flashings, air-control transitions, windows, and doors

Transition the air-control membrane into window and door rough openings and airseal all penetrations through the wall. Flash window and door rough openings and all wall penetrations.

Reinstall windows and doors (or install new windows and doors) in properly flashed openings. Airseal window and door units to the air-control transition membranes at the interior perimeters of window and door units.

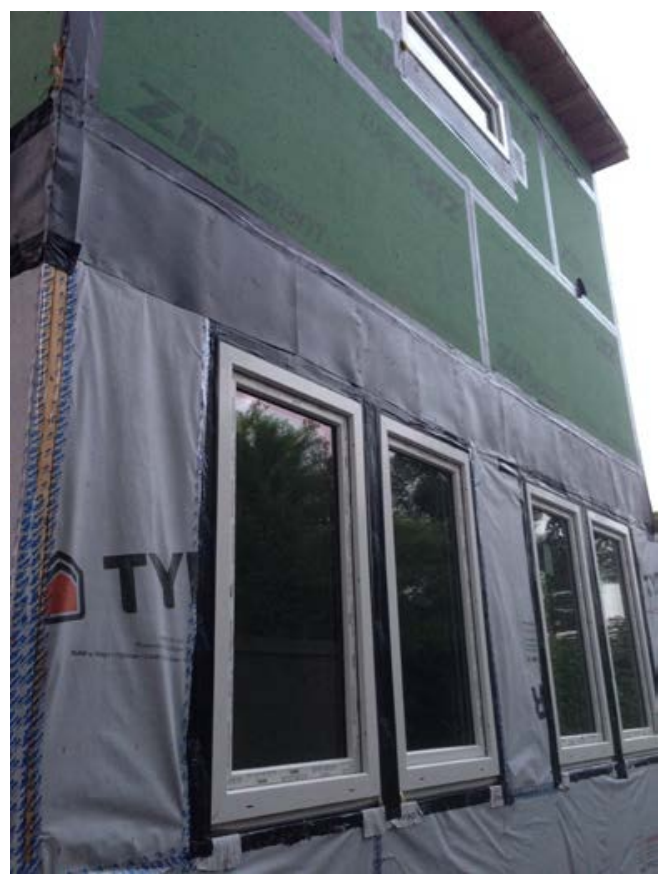

Figure 15. Windows are installed after openings are flashed. 


\section{E. Install new wall cladding and trim}

Install new wall cladding and trim over the water- and air-control membrane. Install spacers to provide a minimum $3 / 8$-in. air gap between the water- and air-control membrane and the new cladding. The spacer options include wood furring strips, polypropylene mesh, a drainage mat, strips of insulating sheathing, plastic manufactured spacer products, etc. (see Lstiburek 2010, $2012 b$ for examples).

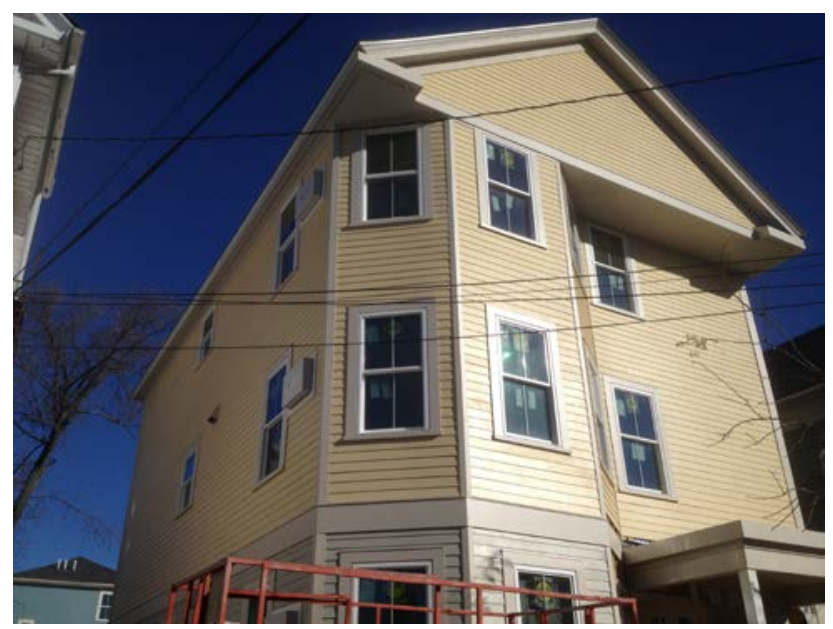

Figure 16. Completed cladding and trim

\section{F. Remove interior finishes}

Remove the existing interior finishes such as plaster or gypsum board. Insulation that fills the wall cavity should also be removed. "Tee" intersection interior walls should have finishes removed to at least the depth of the exterior wall insulated cavity.

Gaps or voids in the sheathing layer may need to be filled. The cavity should be free of dust and debris.

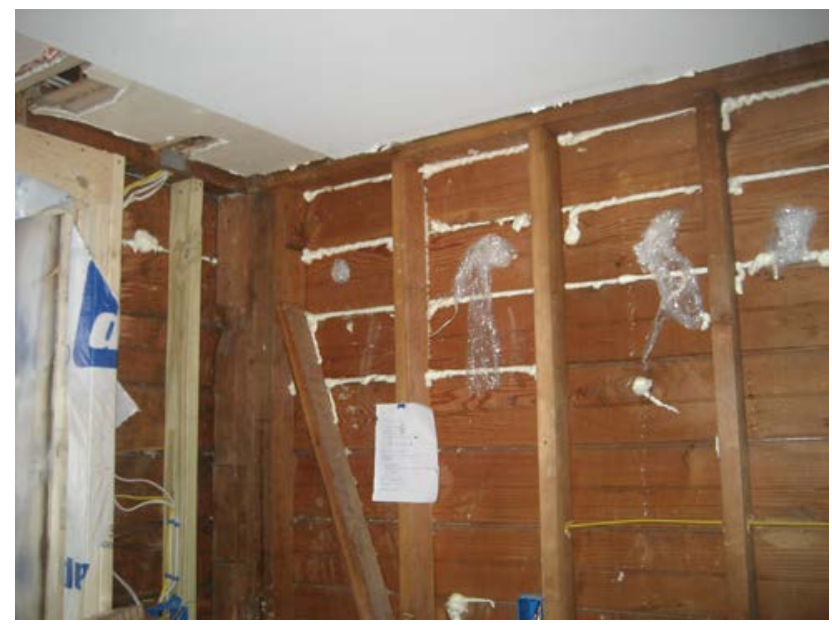

Figure 17. Interior finishes removed

\section{G. Install stud wall and cavity insulation}

Install a new stud wall to the desired depth. Locate the electrical and plumbing services before installing insulation in the cavity. All plumbing pipes should be located within the inner frame 
wall cavity to avoid pipe freeze issues. Insulation outboard of the pipes makes them warmer in winter; insulation inboard of the pipes makes them colder.

Install insulation in the wall cavity according to the detailed drawings and manufacturer's recommendations.

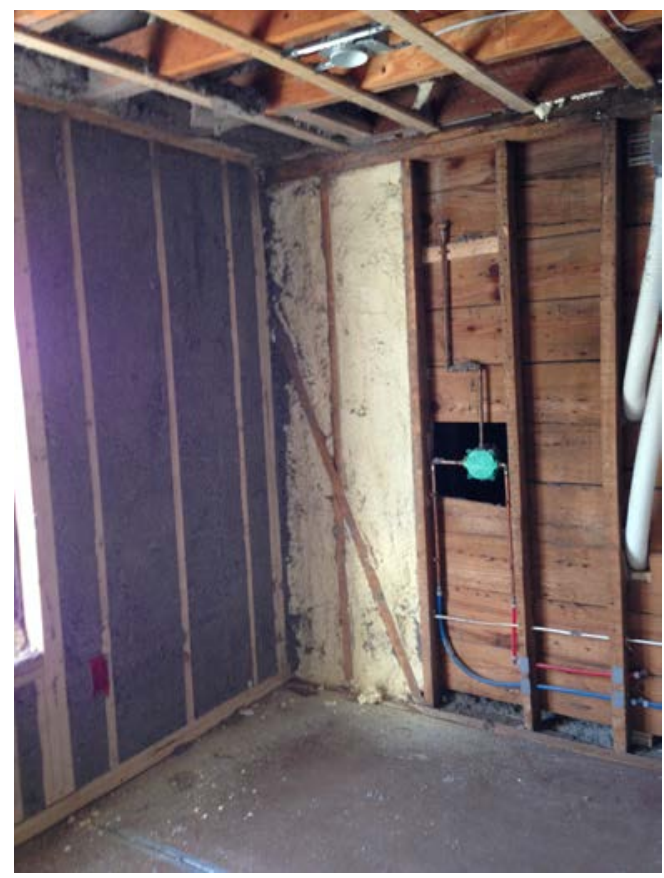

Figure 18. ccSPF and cellulose insulation

\section{H. Install new gypsum board}

Install new gypsum board per standard details. Refer to Section 3 for information about vaporcontrol and air-control layers.

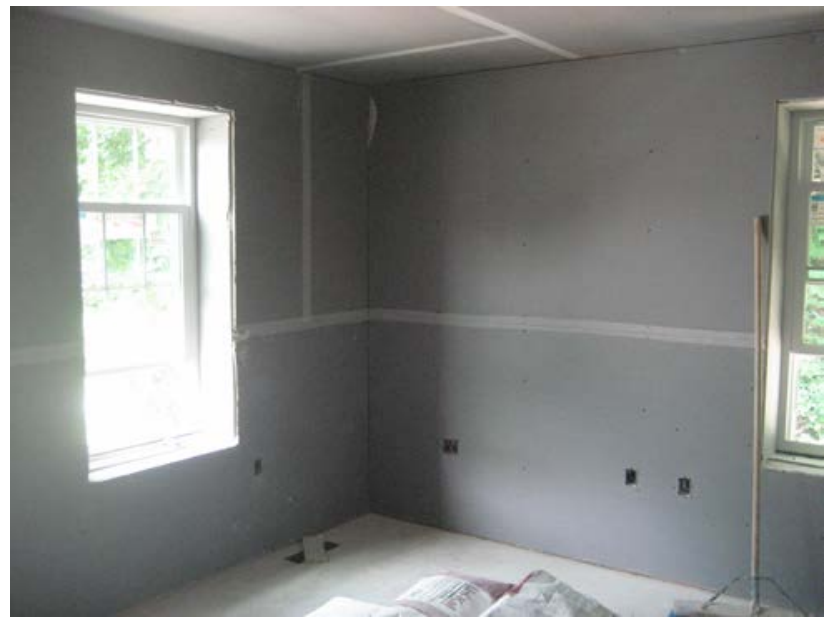

Figure 19. New gypsum board installed 


\subsection{Installation Procedure for Existing Cladding Option \\ A. Retain existing wall cladding and trim}

Retain the existing wall cladding and trim. Repair the cladding as needed. The cladding may be affected depending on which type of cladding system is installed (see Section 3).

\section{B. Remove windows and doors as needed}

Typically, the windows and doors must be removed to allow proper flashing of the window and door openings and to permit the installation of air-control transition membranes.

\section{Install flashings, air-control transitions, windows, and doors}

Transition the air-control layer into window and door rough openings and airseal all wall penetrations. Flash window and door rough openings and all wall penetrations.

Reinstall windows and doors (or install new windows and doors) in properly flashed openings. Airseal window and door units to the air-control transition membranes at the interior perimeters of window and door units.

\section{Remove interior finishes}

Remove the existing interior finishes such as plaster or gypsum board. Insulation that fills the wall cavity should also be removed.

Gaps or voids in the sheathing layer may need to be filled. The cavity should be free of dust and debris.

\section{E. Install stud wall and cavity insulation}

Install a new stud wall at the desired depth. "Tee" intersection interior walls should have finishes removed to at least the depth of the exterior wall insulated cavity.

Locate the electrical and plumbing services before installing insulation in the cavity. All plumbing pipes should be located within the inner frame wall cavity to avoid pipe freeze issues. Insulation outboard of the pipes makes them warmer in winter; insulation inboard of the pipes makes them colder.

Install insulation in the wall cavity per the detailed drawings and manufacturer's recommendations.

\section{F. Install new gypsum board}

Install the new gypsum board per standard details. Refer to Section 3 for information about vapor-control and air-control layers. 


\section{References}

BSC (2009a). "Info-401: Air Barriers-Airtight Drywall Approach." Building Science Corporation, Accessed May 18, 2011: http://www.buildingscience.com/documents/information-sheets/air-barriersairtight-drywall-approach.

BSC (2009b). "Info-408: Critical Seal (Spray Foam at Rim Joist)." Building Science Corporation, Accessed January 27, 2015: http://www.buildingscience.com/documents/information-sheets/criticalseal-spray-foam-at-rim-joist.

ICC (2009a). International Residential Code for One- and Two-Family Dwellings. Country Club Hills, IL: International Code Council, Inc.

ICC (2009b). International Energy Conservation Code. Country Club Hills, IL: International Code Council, Inc.

ICC (2012a). International Residential Code for One- and Two-Family Dwellings. Country Club Hills, IL: International Code Council, Inc.

ICC (2012b). International Energy Conservation Code. Country Club Hills, IL: International Code Council, Inc.

Lstiburek, J. (2006). Builder's Guide to Cold Climates. Westford, MA: Building Science Press.

Lstiburek, J. (2008a). "Building Sciences: Woes_-The Perfect Storm.” ASHRAE Journal February 2008, Atlanta, GA: American Society of Heating, Refrigerating and Air-Conditioning Engineers. Accessed April 13, 2015: http://www.buildingscience.com/documents/insights/bsi-029-stucco-woesthe-perfect-storm.

Lstiburek, J. (2008b). "Building Sciences: Energy Flow Across Enclosures.” ASHRAE Journal August 2008, Atlanta, GA: American Society of Heating, Refrigerating and Air-Conditioning Engineers. Accessed April 13, 2015: http://www.buildingscience.com/documents/insights/bsi-028energy-flow-across-enclosures/.

Lstiburek, J. (2010). “Building Sciences: Mind the Gap, Eh!” ASHRAE Journal January 2010, Atlanta, GA: American Society of Heating, Refrigerating and Air-Conditioning Engineers. Accessed April 13, 2015: http://www.buildingscience.com/documents/insights/bsi-038-mind-the-gap-eh.

Lstiburek, J. (2012a). Water Management Guide. Westford, MA: Building Science Press.

Lstiburek, J. (2012b). "Building Sciences: Hockey Pucks and Hydrostatic Pressure." ASHRAE Journal. January 2012, Atlanta, GA: American Society of Heating, Refrigerating and AirConditioning Engineers. Accessed April 13, 2015:

http://www.buildingscience.com/documents/insights/bsi-057-hockey-pucks-and-hydrostaticpressure/.

Lstiburek, J. (2013). "Building Sciences: Macbeth Does Vapor Barriers (Double, Double Toil and Trouble).” ASHRAE Journal November 2013, Atlanta, GA: American Society of Heating, 
Refrigerating and Air-Conditioning Engineers. Accessed April 13, 2015: http://www.buildingscience.com/documents/insights/bsi-073-macbeth-does-vapor-barriers.

Maines, M. (2011). "Why Flash and Batt Makes Sense." Fine Homebuilding Magazine, February/March 2011, pp. 60-63. Newtown, CT: Taunton Press.

Reed Construction Data (2013). RSMeans CostWorks 2013, 17th Annual Edition. Norwell, MA. Retrieved November 7, 2014.

Straube, J.F. (2011). "Building Science Digest 163: Controlling Cold-Weather Condensation Using Insulation." Accessed January 2015: http://www.buildingscience.com/documents/digests/bsdcontrolling-cold-weather-condensation-using-insulation/.

Ueno, K. (2014). "Monitoring of Double Stud Wall Moisture Conditions in the Northeast." August 2014. Washington, DC: Building America Building Technologies Program, Office of Energy Efficiency and Renewable Energy, U.S. Department of Energy.

Ueno, K.; Wytrykowska, H.; Bergey, D. (2013). Partnering to Build Net-Zero Energy Houses in Massachusetts. Somerville, MA: Building Science Corporation. Accessed January 2015: http://www.buildingscience.com/documents/bareports/ba-1303-new-england-net-zero-newconstruction-evaluations/view. 


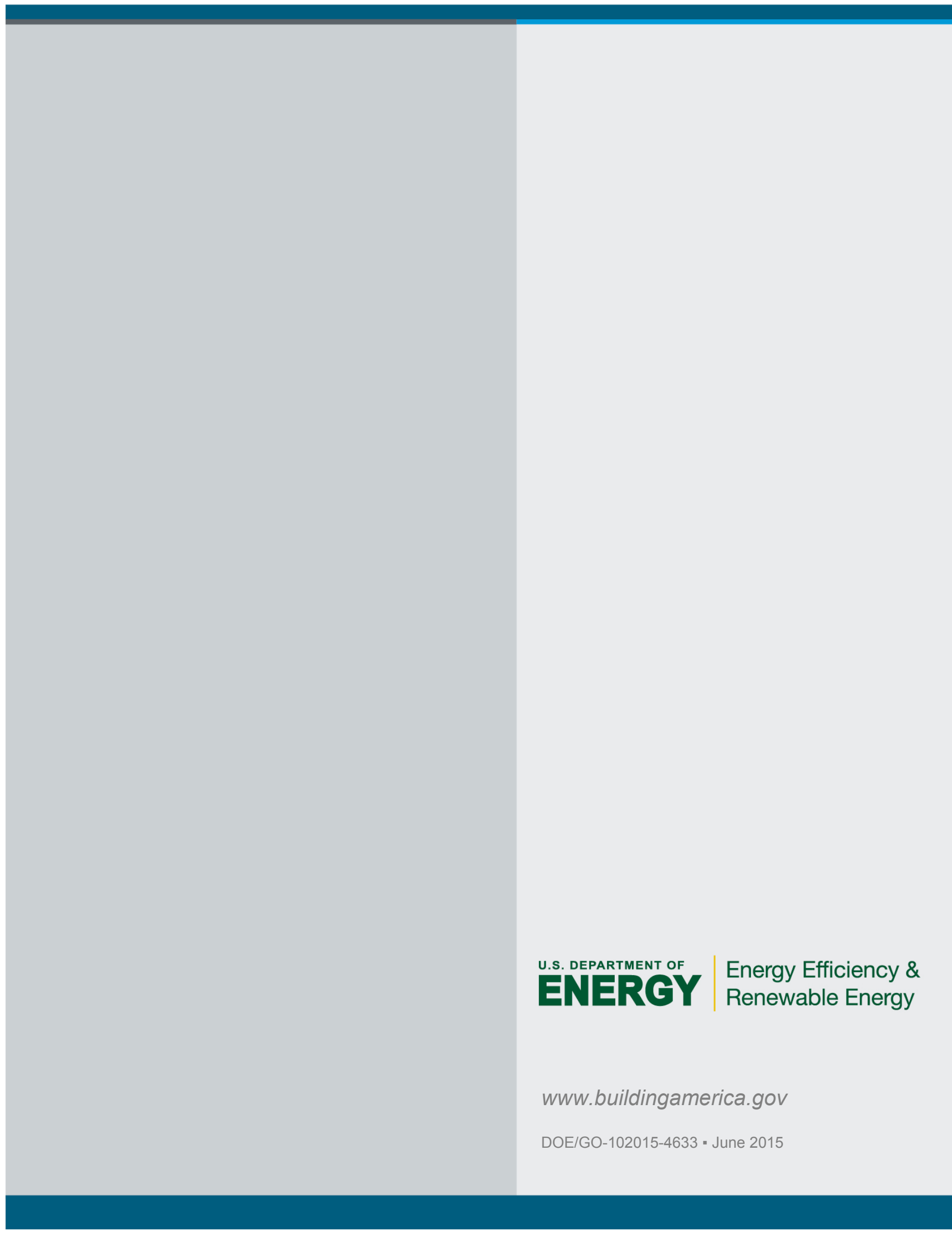

